DOI: http://doi.org/10.4038/ss.v48i2.4711

\title{
Identifying Monetary Policy Rules for Sri Lanka
}

\author{
E.W. Kithsiri J.B. Ehelepola ${ }^{1}$
}

\begin{abstract}
This paper characterises monetary policy of Sri Lanka using policy reaction functions over the period of 1996:Q1 to 2014:Q2, where the Central Bank of Sri Lanka (CBSL) broadly followed a monetary targeting framework in the conduct of monetary policy. The standard Taylor-type and McCallum-type policy rules, augmented with response to exchange rate variations are estimated for three different specifications: contemporaneous, backward looking and forward looking.

The forward looking Taylor rule and the backward-looking McCallum rule capture the monetary policy response in Sri Lanka. Results suggest that more than one-for-one reaction of the nominal interest rate in response to changes in inflation in the forward-looking Taylor specification is desirable as it leads to curtail inflation effectively, assuring determinacy. The coefficient of the output gap is, however, estimated to be larger than that of inflation. It is further evident that the CBSL responds to exchange rate variations only weakly while smoothing out interest rate strongly. A backward-looking McCallum rule where growth rate of monetary aggregate M1 (i.e. narrow money) reacts to growth rate of nominal GDP also seems to characterise monetary policy reaction in Sri Lanka satisfactorily. Strong policy smoothing and weak reaction to exchange rate are also evident in the McCallum rule.
\end{abstract}

Key Words: Monetary Policy, Taylor Rule, McCallum Rule, Monetary Policy Reaction Function, Sri Lanka

JEL Classification: E31; E32; E52; E58; F41

\footnotetext{
${ }^{1}$ The author currently serves as a Deputy Director of the Economic Research Department at the Central Bank of Sri Lanka. Corresponding email: ehelepola@cbsl.com; kehelepola@gmail.com. The author wishes to thank Dr. Denny Lie and Dr. Aarti Singh of the University of Sydney for their valuable advice and comments. Further, the author is thankful to Dr. Lasitha Pathberiya and the anonymous reviewer for their valuable comments on the paper. The author, however, retains sole responsibility for any errors or omissions. The views presented in this paper are those of the author and do not necessarily indicate the views of the Central Bank of Sri Lanka.
} 


\section{Introduction}

A monetary policy rule characterises the extent to which a central bank changes its policy instruments, in response to changes in inflation, output, or any other appropriate economic variables such as exchange rate. A rule based policy approach leads to a low and stable inflation and better economic stability. Such a well-defined policy rule improves transparency and predictability of policy reactions. Moreover, it enhances communication of the monetary policy stance to the market, with a higher certainty which is favourable for a healthy monetary transmission mechanism. This improves accountability while augmenting the long run credibility of the monetary authority (Clarida et al. (1998ba), Woodford (2001b), Woodford and Walsh (2005)). Commitment to follow a rule based monetary policy improves public confidence in the monetary authority, minimising the problem of time-inconsistency arising due to pure discretion. ${ }^{2}$ Modern monetary policy rules, however, allow discretion of the central bank to a certain extent while enabling it to implement feedback reaction, curtailing persistence of various shocks to the economy (Taylor and Williams (2010)). There are two popular policy rules, the Taylor rule and the McCallum rule, that are widely used in capture monetary policy decision making behaviour.

The Taylor rule was originally introduced by Taylor (1993a), who successfully captures monetary policy decision making process by the Federal Reserve Bank of the USA during the period of 1987 to 1992 . Owing to its simplicity, transparency and success reported in the last two decades, many modern central banks use different versions of the Taylor rule in conducting monetary policy. McCallum (1988), on the contrary, introduces a policy rule where the base money growth rate responds to changes in the nominal GDP growth rate. This rule is tested to be more suitable for some economies and Stark and Croushore (1998), for instance, argue that the McCallum rule leads to lower inflation than there has been over the last 30 years, in the US economy. Both rules, Taylor and McCallum, are simple and transparent in nature and aimed at delivering improved macroeconomic performance, smoothing out unexpected fluctuations of few key macroeconomic variables around their targeted paths. They both advocate that central banks should respond to dynamic conditions in an activist manner. ${ }^{3}$ Interestingly, one can use these rules even without specifying a full model for the entire economy.

While there is extensive literature documenting and estimating monetary policy rules in developed economies, the estimation of such rules in emerging and developing countries is limited. This is because of under-developed financial markets and the unavailability of reliable data with sufficiently long-time spans. This study estimates alternative monetary policy rules, of the Taylor type and the McCallum type, for Sri Lanka from 1996:Q1 to 2014:Q2. Present

\footnotetext{
${ }^{2}$ Fundamentally a policy rule limits the discretion of a monetary authority.

3 Activist policy refers to monetary and fiscal policies of a government which believes in active participation in the national economy to effect its economic agenda and objectives.
} 
empirical study, thus allows one to check the appropriateness of an interest rate based policy rule against a monetary targeting policy rule in the context of Sri Lanka. This is important since Sri Lanka is currently in the process of entering into a flexible inflation targeting (FIT) framework, expecting to adopt it fully by 2020. As such, understanding the features of the previous regime's policy reaction function would provide useful insights in implementing the FIT framework effectively. ${ }^{4}$

The rest of the paper is structured as follows: Section 2 reviews literature and provides a brief overview of the monetary policy framework in Sri Lanka; Section 3 discusses the methodology; Section 4 describes the data and provides empirical results, and Section 5 concludes.

\section{Literature Review}

The dialogue on monetary policy rules has a history of over half a century. In 1959 Milton Friedman, for instance, advocated the Federal Reserve an annual increase of the money supply by four percent in order to avoid inflation. Orientation in the focus of the discussion changed when Barro and Gordon (1983) challenged the perception that policy reaction functions necessarily involved fixed values in the policy instrument variable of the central bank. Their argument was based on the inspirations of Kydland and Prescott (1977). This discussion tends to distinguish between the rules vs. discretion dichotomy from the issue of an activist vs. non-activist policy. ${ }^{5}$

Motivated by the influential papers of McCallum (1988) and Taylor (1993a), research activities in the policy rules intensified greatly in the 1990s, creating a huge information base useful for the conduct of monetary policy. ${ }^{6}$ Monetary policy rules, soon became an active area of macroeconomic research, leading to the emergence of different forms and alternative variants of the rules. Clarida and Gertler (1997), for example introduced forward-looking versions of the simple backward-looking policy rule introduced by Taylor (1993a), that proved to be more appropriate in many empirical studies. One important feature of the forward-looking specification is that it allows the monetary authority to consider a number of different information sources (not limited to inflation and output), in forming expectations

\footnotetext{
${ }^{4}$ The CBSL was following a monetary policy framework based on monetary aggregate targeting until around 2015. Then it gradually moved towards enhanced monetary policy framework towards adopting a flexible inflation targeting framework in the medium term. The main monetary policy instruments currently used by the CBSL are: (a) policy interest rates and open market operations (OMO) and (b) the statutory reserve requirement (SRR) on commercial bank deposit liabilities

${ }^{5}$ For details, see for instance, McCallum (1999a)

${ }^{6}$ Taylor (1993b), Fair and Howrey (1996), Rotemberg and Woodford (1997) Levin (1996), Ball (1999), McCallum (1999b), Bernanke and Woodford (1997), Clarida and Gertler (1997) Orphanides (2001), Fuhrer and Madigan (1997), Svensson (2000) are among them.
} 
of the future state of the economy. Further, Clarida et al. (1998b) argue that some form of inflation targeting is better than fixing exchange rates as a means of gaining a nominal anchor in monetary policy conduct.

Macroeconomic data series such as inflation and output gap used in estimating monetary policy rules are subject to various errors and frequent revisions. As Orphanides (2001) emphasises, one main practical hindrance in the implementation of monetary policy is the difficulty of obtaining appropriate measurements for the required variables. Neither the output gap nor the equilibrium real interest rate are observable, and hence possible errors associated with estimating these latent variables together with the uncertainties of the processes of determining them add up to total measurement errors (see for instance, Orphanides and Van Norden (2002) and Edge et al. (2010) for details). Based on the results of several studies on the implications of errors in measuring the output gap in monetary policy rules, ${ }^{7}$ Taylor and Williams (2010) state that the size of the coefficient on the output gap changes due to errors in measuring the output gap.

Whether the role of the exchange rate is vital or not in the monetary policy rule is also an important question. This could be very relevant for a small open economy such, as Sri Lanka, which is vulnerable to various external shocks. Ball (1999) uses a small open economy to evaluate the importance of the exchange rate in the monetary policy rule and concludes that the inclusion of exchange rate in simple monetary policy rules improves the macroeconomic performance in the model. He incorporates both contemporaneous and first-lag values of exchange rate as explanatory variables in a simple monetary policy rule and finds that the standard deviation of the output can be reduced significantly by introducing exchange rate, holding inflation variability unchanged. In a detailed analysis of the role of the exchange rate in monetary policy rules, Taylor (2001), however, finds that monetary policy rules that reacts directly to the exchange rate, in addition to the fact that the output and inflation do not work better in stabilising inflation and real output and occasionally underperform than the rules that react to exchange rate only indirectly, in the context of the US economy.

Taylor (1993b) finds that a certain degree of interest rate inertia in the monetary policy rule can significantly improve performance of a forward-looking model such as the Federal Reserve Board's FRB/US large scale rational expectations model. Central banks tend to smooth changes in interest rates for the obvious reasons, such as fear of disrupting capital markets, possible losses of credibility due to large/abrupt policy rate reversals and the necessity of consensus building to support a particular policy change (Clarida et al. (1998a)).

Zero Lower Bound (ZLB) on interest rates is another important concern which is discussed in relation to monetary policy rules by many, including Orphanides et al. (1998) and Taylor

${ }^{7}$ This include, Orphanides et al. (1998), Gerlach and Smets (1999), Orphanides (2001), McCallum (2001), and Rudebusch (2001). 
and Williams (2010). Though cash is an asset, it pays zero interest and therefore, short term interest rate will not go below zero for a long period. This limitation of the interest rate is a hindrance to proper conduct of monetary policy aiming at minimising inflation and output fluctuations. ${ }^{8}$ Several concerns of monetary policy rules, arising from Zero Lower Bound are identified by Taylor and Williams (2010) including (1) possibility of existence of multiple steady states, (2) implications for the specification and parametrisation of the monetary policy rule, (3) tendency towards a higher target inflation rate than otherwise would be the case.

Taylor and Williams (2010) find that simple normative rules are robust and perform well in a variety of novel and rigorous models and policy evaluations. They further argue that such simple rules work better and lead to improved macroeconomic performance when decisions are based on such rules. There are some inherent informational difficulties, however, associated with implementation and interpretation of simple monetary policy rules. In a related study, Orphanides (2001) emphasises that policy rules estimated by using revised expost data could lead to outcomes that are much different from the actual historical reality. It could possibly suggest a different behaviour of the monetary authority than the one it faced with real time information, obscuring the truth.

In the recent years, a considerable number of studies have taken place on monetary policy rules and related areas in developing countries. ${ }^{9}$ These studies mainly attempt to estimate alternative monetary policy rules for their respective countries. Many of these studies focus on Taylor type policy rules with quarterly data and found that forward-looking specifications work well (Perera and Jayawickrema (2014), ${ }^{10}$ for instance) while others use McCallum type policy rules only (Kozmenko and Savchenko (2013), for instance), for the purpose. Some of them, however, use both types, as well as hybrid versions of the two rules (as reported in Esanov et al. (2005), Khakimov et al. (2010) and Patra and Kapur (2012)). These studies suggest that there is no any universal rule which suits all countries in all periods. Instead they found that different rules are preferred in different countries and even within a country, some rules work better than others under different policy regimes.

\footnotetext{
${ }^{8}$ For details, see for example Fuhrer and Madigan (1997), Eggertsson and Woodford (2003) and Chung et al. (2010)

${ }^{9}$ Esanov et al. (2005) for Russia, Khakimov et al. (2010) for Turkey, Aleem and Lahiani (2011) for Pakistan, Patra and Kapur (2012) for India, Wimanda et al. (2012), Boamah (2012) for Ghana, Kozmenko and Savchenko (2013) for Ukraine and Perera and Jayawickrema (2014) for Sri Lanka, are among them.

${ }^{10}$ Perera and Jayawickrema (2014) characterise the monetary policy decision making process for Sri Lanka using standard Taylor-type monetary policy rules. Further, they have estimated alternative monetary policy reaction functions for Sri Lanka over the period 1996Q1 to 2013Q2. However, their discussion was limited to Taylor type policy rules, thus refraining from any discussions on McCallum-type policy rules.
} 


\subsection{A brief discussion of Sri the Lankan Monetary Policy Framework}

The Monetary Law Act of 1949 established the Central Bank of Sri Lanka (CBSL) to administer and regulate the monetary system of the country. It specifies the function of, confers powers, and imposes responsibilities upon the Monetary Board of the CBSL which is the monetary policy decision making authority in Sri Lanka. As such, the monetary policy targets are determined by the Monetary Board and the CBSL conducts monetary policy, broadly, by managing cost of money (i.e. interest rate) and availability of money (i.e. credit availability).

The CBSL has been following a monetary targeting framework in monetary management in Sri Lanka. Since the 1980s, the final target of price stability is accomplished by influencing the broad money supply that is closely connected with reserve money through a multiplier, in this framework. The CBSL employs a monetary programme, prepared by considering various macroeconomic elements, including the balance of payments developments, expected economic growth, desired levels of credit and inflation, exchange rate dynamics and anticipated fiscal balances, in assessing the required monetary growth. This enables determination of quarterly reserve money targets necessary to achieve the expected monetary growth.

Over the last two decades, the CBSL has gradually adopted a market oriented monetary management policy framework, instrumented with policy interest rates, replacing the nonmarket oriented policy instruments while minimising direct controls on interest rates and credit. Important milestones in this evolutionary process include introduction of the Repurchase (Repo) facility in October 1993, Reverse Repurchase (Reverse Repo ${ }^{11}$ ) facility in November 1998 and comprehensive open market operations (OMO) in March 2003. The CBSL started to use two main monetary policy instruments: first, policy interest rates (interest rates on overnight repurchase and reverse repurchase agreements) with open market operations and second, the statutory reserve requirement (SRR) on commercial bank deposit liabilities.

The CBSL conducts its Open Market Operations within a corridor of interest rates formed by its policy rates (i.e. the repurchase rate and the reverse repurchase rate), in achieving the expected reserve money target. Regular reviews and revisions are made to the policy rates as required, to ensure that the reserve money is in its targeted path. When the CBSL made changes in the repurchase rate or the reverse repurchase rate, an instantaneous revision can be observed in the inter-bank call money market and then in other flexible short-term rates including Treasury bill rates and prime lending rates. This in turn, tends to influence a set of different interest rates at which commercial banks and other financial institutions

\footnotetext{
${ }^{11}$ Under present terminology, Repo and reverse Repo are known as the Standing Deposit Facility Rate (SDFR) and the Standing Lending Facility Rate (SLFR), respectively.
} 
lend/borrow, with different time lags. Subsequently, it influences consumption/ investment decisions and thereby aggregate demand, affecting cost of production, wages and prices in the economy. As opposed to the OMO, the statutory reserve ratio (SRR) ${ }^{12}$ has not been frequently used as a means of controlling money supply.

The CBSL observed over the period that the correlation between the monetary aggregates and the central bank policy rates was becoming weak, as noticed in several other countries in different time periods. Accordingly, in early 2017 CBSL announced its expectation to transit to flexible inflation targeting framework (FIT) ${ }^{13}$ in 2020. The CBSL at present conducts monetary policy within an enhanced monetary policy framework which shares features of both monetary targeting and FIT. This framework enables the CBSL to stabilise inflation in mid-single digits over the medium term, while facilitating economic growth and flexibility in exchange rate management. As such, the CBSL uses several policy instruments to guide short term interest rates in conducting the monetary policy and employs average weighted call money rate (AWCMR) as the operating target.

Under the FIT regime, CBSL will announce the inflation target for a period and adjust interest rates accordingly. The strategy is expected to maintain price stability and thereby pave the way to progress as an upper middle-income economy over the medium term. The CBSL has formulated a 'Road Map' for the adoption of FIT, outlining the necessary reforms, the amendment of the Monetary Law Act, to accommodate such a monetary policy formulation regime, and innovations relevant to institutional features, operational features, monetary policy implementation, exchange rate policy and foreign exchange operations as well as capacity building, to facilitate the smooth transition to the new regime. In addition, the Central Bank continues to strengthen monetary policy communication with relevant stakeholders, in line with the growing importance of effective communication in monetary policy transmission. Further, a notable progress has been made in fulfilling the requirements pertaining alignment of both fiscal and monetary policy towards achieving inflation targets in a coherent manner which are essential for successful implementation of FIT (CBSL 2017, 2018).

\footnotetext{
${ }^{12}$ This refers to the fraction of the obligatory deposit liabilities that commercial banks are mandatory to keep as a cash deposit with the CBSL.

13 According to Bernanke and Mishkin (1997), inflation targeting approach is characterised, as the name suggests, by the announcement of official target ranges for the inflation rate at one or more horizons, and by explicit acknowledgment that low and stable inflation is the overriding goal of monetary policy. Other important features of inflation targeting include increased communication with the public about the plans and objectives of the monetary policymakers, and, in many cases, increased accountability of the central bank for attaining those objectives.
} 


\section{Methodology (Different Types of Monetary Rules)}

This study focuses on Taylor rule type specifications since the CBSL used policy interest rate as the main conducting instrument in monetary policy during the period under consideration. The CBSL used monetary targeting policy framework and accordingly, the study also analyses suitability of the McCallum type types of policy rules for the country. These two types of rules are estimated and compared with lagged, contemporaneous and forward-looking specifications as it is worthwhile to test all of them, without taking any priori presumptions, in selecting the most suitable rule in explaining the behavior of monetary policy formulation.

\subsection{Taylor rule specifications}

Taylor (1993a) finds that the Federal Reserve usually calls for changes in the federal funds rate in response to changes in either the price level or changes in real income. Thus, the Taylor rule specifies the short-term interest rate $\left(i_{t}\right)$ as follows:

$$
i_{t}=r^{*}+\pi_{t}+\emptyset_{\pi}\left(\pi_{t}-\pi^{*}\right)+\emptyset_{y} y g a p_{t}
$$

where, $r^{*}$ is the equilibrium real interest rate, $\pi_{t}$ is the inflation rate in period $t, \pi^{*}$ denotes the inflation target and $\operatorname{ygap}_{t}$ is the output gap which is the deviation of real GDP from its potential level. The magnitude of the coefficients $\emptyset_{\pi}$ and $\emptyset_{y}$ denotes the aggressiveness of the policy reaction of the central bank, for which he assigned values 0.5 each. The equation (1) above says in essence that in the steady sate where inflation equals its target and the output gap equals zero, the real interest rate (i.e. the nominal interest rate net of expected inflation) equals the equilibrium real interest rate. The rule implies that the monetary authority sets the nominal interest rate above (below) the steady state level interest rate, when inflation is above (below) the target and/or output is above (below) its potential level, and vice-versa.

The original Taylor rule, first presented in Taylor (1993a), set $r^{*}$ equal to 2 and the $\pi^{*}$ equal to 2 as well. Accordingly, the equation (1) can be arranged as, $i_{t}=\pi_{t}+0.5 y g a p_{t}+$ $0.5\left(\pi_{t}-2\right)+2$, or equivalently, as follows:

$$
i_{t}=1+1.5 \pi_{t}+0.5 y g a p_{t}
$$

This says that the short-term interest rate equals one and a half times the inflation rate plus one half times the output gap plus one. ${ }^{14}$ Simulation studies reveal that this equation works well with US data.

\footnotetext{
${ }^{14}$ Taylor (1993) uses quarterly data and used a moving average of inflation over four quarters.
} 
The Taylor rule suggests two important results in stabilising inflation and output: (1) the more than one-for-one response to inflation which is referred to as the Taylor principle ${ }^{15}$ by Woodford 2001b: When inflation starts to increase, the Taylor rule advocates for the monetary authority to raise the interest rate more rapidly to curtail inflationary pressure; and (2) the leaning against the wind character: which means increasing the interest rate when output exceeds its potential level and vice-versa. Hence, the monetary authority's reaction enables it to bring back both the inflation and output, whenever they deviate from their corresponding targets.

Research examining the monetary policy reaction functions in emerging markets suggests that open economy rules in which policy instruments respond to deviation of exchange rate $(\Delta \mathrm{et})$, in addition to the output gap and inflation deviation, perform better than the closed economy version of the model. Being a small open economy with increased foreign exchange transactions and sovereign bond issues, foreign exchange management could also have a bearing on monetary policy in Sri Lanka. Accordingly, I follow Patra and Kapur (2012), Llosa and Tuesta (2008) and Araujo (2014), where the original Taylor rule is augmented with exchange rate deviation and a certain degree of interest rate inertia, as follows:

- Contemporaneous version

$$
i_{t}=\emptyset_{0}+\emptyset_{\pi}\left(\pi_{t}-\pi^{*}\right)+\emptyset_{y} \operatorname{ygap}_{t}+\emptyset_{e} \Delta e_{t}+\emptyset_{i} i_{t-1}+\varepsilon_{t}
$$

- Backward-looking version

$$
i_{t}=\emptyset_{0}+\emptyset_{\pi}\left(\pi_{t-1}-\pi^{*}\right)+\emptyset_{y} y_{g a p_{t-1}}+\emptyset_{e} \Delta e_{t-1}+\emptyset_{i} i_{t-1}+\varepsilon_{t}
$$

- Forward-looking version

$$
i_{t}=\emptyset_{0}+\emptyset_{\pi}\left(E_{t}\left[\pi_{t+1}\right]-\pi^{*}\right)+\emptyset_{y} E_{t}\left[\operatorname{ygap}_{t+1}\right]+\emptyset_{e} E_{t}\left[\Delta e_{t+1}\right]+\emptyset_{i} i_{t-1}+\varepsilon_{t}
$$

where, $E_{t}$ is the expectations operator, $\emptyset$ terms are the corresponding coefficients and $\varepsilon_{t}$ is an error term capturing any deviations from the Taylor rule. Other symbols denote the same quantities, as above. For each of the above three specifications, two cases, one including and the other excluding exchange rate, are tested. Further, two alternative candidates for the monetary policy instrument (i.e. short run interest rate), which are the Average weighted call money rate and the 91-day Treasury bill rate are used in each case.

\footnotetext{
15 This condition is required in most of the macroeconomic models to ensure existence of a determinate solution, as explained in detail in Woodford, 2003.
} 


\subsection{McCallum Rule Specifications}

McCallum $(1988,2000)$ explains the monetary policy rule that relates the policy instrument and growth of the reserve money, to the target variable which is the growth rate of nominal GDP, as follows:

$$
\Delta m_{t}=\Delta x^{*}-\Delta v_{t}^{a}+\lambda\left(\Delta x^{*}-\Delta x_{t-1}\right)
$$

where, $\Delta m_{t}, \Delta v_{t}^{a}, \Delta x_{t}$ and $\Delta x^{*}$ denote the growth rates of the base money, base velocity, nominal GDP and nominal GDP target respectively ${ }^{16}$ and $\lambda$ is the coefficient of deviation of GDP growth rate from its target. ${ }^{17}$

The McCallum Rule consists of three main parts: (1) the target for the current growth of nominal GDP, (2) a moving average adjustment for the variations in velocity and (3) a difference between the nominal GDP growth with its target value. In essence, the rule targets nominal GDP growth by setting the growth rate of money supply, allowing the economy to expand at its normal pace, stabilising inflation indirectly.

The velocity term captures the long run demand changes for the base money stock, attributable to the technological advancements or regulatory variations taking place. Not all changes in money base are attributable to velocity changes; velocity change is intended to capture variations in the long run trend only (McCallum and Nelsson, 1989). The cyclical changes, on the other hand, are reflected by the final term which recommends a downward adjustment to the base money growth (i.e. tightening the monetary policy stance) when $\Delta x_{t-1}$ is above $\Delta x^{*}$ and vice-versa.

The policy instrument used in the McCallum rule is the high-powered money (reserve money). It is, however, important to make necessary adjustments to the reserve money aggregate so as to account for the changes in the Statutory Reserve Requirement (SRR) during the period of analysis (McCallum 1990, 2000).

The main parameter in the McCallum rule is the coefficient on the GDP deviation term, $\lambda$. This explains how much the money base should be changed in response to a nominal GDP variation from its target, $\left(\Delta x^{*}-\Delta x_{t-1}\right)$. A large value for the response coefficient could lead of the monetary policy in influencing the economy. ${ }^{18}$

It is also important to note that in the McCallum rule, nominal GDP variation from its target is measured as the target value minus the realised value, in contrast to the Taylor Rule which

\footnotetext{
${ }^{16}$ For the US, McCallum assumed it to be 5 percent

${ }^{17}$ McCallum (1993) set $\lambda=0.5$, for the US.

${ }^{18}$ Among others, McCallum (2000), Croushore and Stark (1996), Hall (1990) suggest $\lambda=0.5$, for the U.S. economy.
} 
defines the deviations as the realised value minus target. Accordingly, when the GDP growth is less than the target for example, the rule together with the positive coefficient $\lambda$ advocates an expansionary monetary policy stance with an increase in reserve money growth rate.

The McCalllum rule uses average growth of base velocity over the previous 16 quarters in characterising the rule. This is a major hindrance in estimating the rule for a country with a short data span, since it requires discarding a large number of observations so as to average the velocity of money over the four-year period. In developing countries, reliable quarterly velocity data are either unavailable or available only for a limited short period. Thus, authors including Esanov et al. (2005) and Patra and Kapur (2012) adopt variants of the McCallum rule, avoiding the velocity term. Omitting the velocity term does not make much difference, if the growth rate of base velocity is nearly constant over the period. ${ }^{19}$ Annual velocity figures for Sri Lanka reveal that it has been stable around an average of 3.38 over the last 30 years with an annual average growth rate of only -0.49 percent ${ }^{20}$ and hence the contribution of the velocity growth term is negligible. Considering the above and the fact that Sri Lanka do not have quarterly velocity data, I use a McCallum rule specification, which excludes the velocity term.

Similar to the extended Taylor rule above, Esanov et al. (2005) and Patra and Kapur (2012) use additional terms for policy smoothing and exchange rate variation which could be relevant in the Sri Lankan context, too. Accordingly, I use the following rules:

- Backward-looking model;

$$
\Delta m_{t}=c_{1}+c_{2}\left(\Delta x^{*}-\Delta x_{t-1}\right)+c_{3} \Delta e_{t-1}+c_{4} \Delta m_{t-1}
$$

- $\quad$ Forward-looking model ${ }^{21}$

$$
\Delta m_{t}=c_{1}+c_{2}\left(\Delta x^{*}-\Delta E_{t} x_{t+1}\right)+c_{3} \Delta E_{t} e_{t+1}+c_{4} \Delta m_{t-1}
$$

In each of the above two cases, two specifications (one including and the other excluding exchange rate) are tested. Further, two alternative candidates for the monetary policy instrument, which are the Reserve money (adjusted for the Statutory Reserve Requirement (SRR)) and the Narrow money are used.

\footnotetext{
${ }^{19}$ This leads to an approximately zero-base velocity growth, thus, justifying the omission of the velocity term.

${ }^{20}$ Data source: Special Appendix - Annual Report of the CBSL (2014)

${ }^{21}$ The original McCallum rule is presented in the backward-looking form. Following Patra and Kapur (2012), I use both backward-looking and forward-looking specifications of the McCallum rule.
} 


\subsection{Monetary policy rule and determinacy}

The question of whether a policy rule proposed is associated with a unique determinate solution is an important consideration in deciding on the most suitable alternative policy rule among several alternatives (Bernanke and Woodford (1997), Clarida et al. (1998a), Bullard and Mitra $(2002,2007)$ ). Some types of policy rules are associated with large sets of rational expectations equilibria out of which some may cause fluctuations in key variables in the model such as inflation or real output, entirely attributing to self-fulfilling expectations. Accordingly, such equilibria should be prevented from selecting paths with economic stability. Monetary authorities have shown a tendency towards smoothing out the nominal interest rate, in response to fluctuations in the economy. When it decides to change the nominal rate, the central banks, in fact practically implement it as a sequence of small deviations in the desired single direction which will sum up to the expected total change. Bullard and Mitra (2007) consider two variants of the monetary policy reaction functions suggested by Taylor (1993a, 1999a,b) and conclude that monetary policy inertia enhances the prospects for equilibrium determinacy and learnability in a standard, small, forwardlooking model. Accordingly, the analytical conditions which ensure determinacy in the two cases, including interest rate smoothing and excluding it, are discussed below.

\subsubsection{Determinacy in the absence of interest rate smoothing}

With a greater emphasis, Taylor (1993b, 1999a) argues that it is important to respond to inflation above the target rate, by raising the nominal interest rate operating target by more than the amount by which inflation exceeds the target. Taylor (1999a) attributes the Federal Reserve's failure to adhere to this principle, to the large macroeconomic instability in the U.S. in the pre-Volcker period.

Woodford (2003) considers a Taylor rule of the form:

$$
i_{t}=\phi\left(\frac{\Pi_{t}}{\Pi_{t}^{*}} ; v_{t}\right)
$$

where, $\Pi_{t}=\frac{P_{t}}{P_{t-1}}$ is the gross inflation, $\Pi_{t}^{*}$ is the inflation target, possibly time varying, and $v_{t}$ represents exogenous factors which shifts this relation and $\phi(. ; v)$ is an increasing function for each value of $v$. A log-linear approximation to the above rule is given by,

$$
\hat{\imath}_{t}=\phi_{\pi}\left(\pi_{t}-\pi^{*}\right)+v_{t}
$$


where $\pi^{*}=\log \Pi_{t}^{*}$ and $\phi_{\pi}>0$ is the elasticity of $\phi$ with respect to its first argument. This can be rearranged as,

$$
\hat{\imath}_{t}=\bar{\imath}_{t}+\phi_{\pi} \pi_{t}
$$

where $\bar{l}_{t}=v_{t}-\phi_{\pi} \pi_{t}^{*}$ measures the total exogenous shift in the monetary authority's reaction function. For a simple interest rate feedback rule of the above form, the rational-expectations equilibrium paths of inflation and nominal interest rate are determinate when the inflation coefficient, $\phi_{\pi}>1$ and it is indeterminate, if instead, $0 \leq \phi_{\pi}<1$.

\subsubsection{Determinacy in the presence of interest smoothing}

Policy reaction functions of the central banks typically include partial-adjustment dynamics of one or more than one lagged values of the interest rate. Specifically, it incorporates the idea that the current setting of the nominal interest rate is influenced positively by the lagged values of itself, besides the variables representing current economic conditions. Clarida et al. (1998b) among others, stress the importance of incorporating interest rate smoothing into the policy rule. Woodford (2003), for example considers a simple feedback rule with interest rate smoothing, as follows, to illustrate the determinacy conditions in such a case:

$$
\hat{\imath}_{t}=\bar{l}_{t}+\rho\left(\hat{\imath}_{t-1}-\bar{l}_{t}\right)+\phi_{\pi} \pi_{t}
$$

The symbols carry their usual meanings as given above. Now, the coefficient $\rho \geq 0$ measures the degree of intrinsic inertia in the monetary authorities operating target.

When $\rho \leq 1$, the above rule can be solved backward, eliminating the dependence of lagged interest rate. In this new rearranged representation, the inflation response coefficient corresponds to $\phi_{\pi} /(1-\rho)$. Thus, in line with the Taylor principle, Woodford (2003) argues that equilibrium is determinate if and only if,

$$
\frac{\phi_{\pi}}{(1-\rho)}>1
$$

Accordingly, he interprets this condition as the case where eventual increase in the nominal interest rate as a result of the sustained increase in the inflation rate, is more than one- forone. Well-behaved rational expectations equilibria can, however, exist even when $\rho \geq 1$. From the above inequality, it implies that for $\rho<1$, the equilibrium inflation rate is determinate if and only if $\phi_{\pi}>0$ and $\phi_{\pi}+\rho>1$

This condition is valid more generally when $\rho \geq 1$, any positive value for $\phi_{\pi}$ is sufficient for determinacy and in fact, when $\rho>1$, the equilibrium is determinate for the case where $\phi_{\pi}$ is slightly negative. It is however required that $\phi_{\pi}$ be not equal to zero to ensure determinacy. 
The inflation response coefficient $\phi_{\pi} /(1-\rho)$ above is referred to as the long-run inflation response coefficient, by many authors including Nelson (2001) and Woodford (2003).

\subsubsection{Determinacy in the presence of interest rate smoothing, while responding to both}

\section{inflation and output}

Gali (2009) analyses the determinacy condition for a Taylor type monetary policy reaction function of the following form, which responds to both inflation and output, ${ }^{22}$

$$
i_{t}=\rho+\phi_{\pi} \pi_{t}+\phi_{y} \operatorname{ygap}_{t}+u_{t}
$$

where, $u_{t}$ is an exogenous component with zero mean, coefficients $\phi_{\pi}, \phi_{y}>0$ are selected by the monetary authority, the intercept $\rho$, makes the rule consistent with a zero-inflation steady state. ${ }^{23}$ Considering a system of equations consists of the above policy rule, together with a New Keynesian Phillips curve and a dynamic IS curve, Gali (2009) specifies the necessary and sufficient condition for uniqueness as follows: ${ }^{24}$

$$
\kappa\left(\phi_{\pi}-1\right)+(1-\beta) \phi_{y}>0
$$

where $\beta$ is the discount factor, ${ }^{25} \kappa$ is a parameter. ${ }^{26}$ Thus, the central bank should respond to any deviations of inflation and output gap from their respective targets, by changing the policy interest rates with sufficient strength to assure a unique solution for the equilibrium.

\section{Empirical Analysis}

\subsection{Data Description}

I use quarterly data from 1996:Q1 to 2014:Q2 for this study. The selection of this particular period is due to the availability of quarterly data for many key macroeconomic variables in Sri Lanka, as well as the conduct of the monetary aggregates targeted monetary policy framework in the county, during the said period. The growth rates are calculated on a quarter-to-quarter basis and each of the data series used for the study and their sources are shown in the Table 1 given below.

\footnotetext{
${ }^{22}$ For details, see chapters 3 and 4 of Gali (2009).

${ }^{23}$ Note that the inflation target in this case is also zero.

${ }^{24}$ See Bullard and Mitra (2002) for a proof.

${ }^{25}$ Note that $\rho=-\log \beta$

${ }^{26}$ Gali (2009) defines $\kappa$ such that $\kappa=\lambda\left(\sigma+\frac{\phi+\alpha}{1-\alpha}\right)$ such that $\lambda=\left(\frac{(1-\theta)(1-\beta \theta)}{\theta}\right)\left(\frac{1-\alpha}{1-\alpha+\alpha \varepsilon}\right)$ where $\theta$ is the Calvo price stickiness parameter, $\alpha$ is the share of total income that goes to capital, $\varepsilon$ is the elasticity of substitution among different varieties of goods, $\phi$ is the inter temporal elasticity of labour and $\sigma$ is the inter temporal elasticity of substitution parameter.
} 
Table 1: Data series and derived variables used in estimating rules

\begin{tabular}{lll}
\hline \hline Variable $^{\mathrm{a}}$ & Description $^{\mathrm{b}}$ & Source $^{\mathrm{c}}$ \\
\hline$A W C M R\left(i_{t}\right)$ & Average weighted call money rate (quarterly average) & CBSL \\
$\operatorname{TBR}\left(i_{t}\right)$ & Treasury bill rate (91 day) & CBSL \\
$\operatorname{EXRVAR}\left(\Delta e_{t}\right)$ & Variation in the quarterly average exchange rate & CBSL \\
$\operatorname{INFGAP}\left(\pi_{t}-\pi^{*}\right)$ & Deviation of inflation from the implied target ${ }^{\mathrm{d}}$ & DCS, AE \\
$Y\left(y_{t}\right)$ & Nominal GDP & CBSL, DCS \\
$Y G A P\left(y_{t}-\tilde{y}_{i}\right)$ & Output gap; deviation of output from the its long term rend ${ }^{\mathrm{e}}$ & CBSL, DCS, AE \\
$\operatorname{NDGPg}\left(\Delta x_{t}\right)$ & Nominal GDP growth (quarter-on-quarter growth) & CBSL, DCS \\
$A R M g\left(\Delta m_{t}\right)$ & Growth rate of Reserve Money ${ }^{\mathrm{f}}$ & CBSL \\
$M_{t_{g}}\left(\Delta m_{t}\right)$ & Growth rate of Narrow Money, $\mathrm{M}_{1}$ & CBSL \\
$M_{2 g}\left(\Delta m_{t}\right)$ & Growth rate of Narrow Money, $\mathrm{M}_{2}$ & CBSL \\
\hline
\end{tabular}

${ }^{a}$ In the models, either AWCMR or TBR is used as the policy instrument (not both).

b All these quantities are expressed as percentages.

c Abbreviations used are as follows; CBSL: Central Bank of Sri Lanka, MoFP: Ministry of Finance and Planning, AE: Author's Estimates, DCS: Department of Census and Statistics of Sri Lanka.

d Inflation is computed by using the Colombo Consumer's Price Index.

e Approximated by the HP trend.

${ }^{\mathrm{f}}$ This is after making adjustments to the Statutory Reserve Requirement.

Preliminary data testing is useful in identifying possible data issues. ${ }^{27} \mathrm{I}$ plot all the data series first to check for any possible outliers, trends, discontinuities, changes in variability etc. Time plots of the key variables used in the study with a brief discussion are given in the following paragraphs.

Several alternative variables are used as the monetary policy instruments in related literature. In the Taylor rule specifications, short term interest rate, as reflected by 91 -day Treasury bill rate, call money market rate and Repo, and reverse Repo rates are widely used in many studies while some alternatives such as effective policy rate ${ }^{28}$ are also employed in other studies. The monetary policy stance of the CBSL is reflected by the short-term interest rates since the introduction of Open Market Operations. In this study, thus, the weighted average call money market rate (AWCMR) and 91-day Treasury bill rate (TBR) are used as the two alternative candidates for the monetary policy instrument in the Taylor rule specification. The Figure 1 given below shows that the AWCMR and TBR, move hand in hand displaying a close relationship with a strong correlation coefficient of 0.91 .

\footnotetext{
${ }^{27}$ see for instance, Boschen and Mills (1992) and Hafer and Kutan (1997)

${ }^{28}$ For instance, Patra and Kapur (2012), Perera and Jayawickrema (2013) use a so called effective policy rate, which is the interest rate through which the central bank engaged in its liquidity operations with market participants, depending on prevailing liquidity conditions (in most of the time it is as same as either Repo or Reverse repo rate. The current study does not employ it since the data series is non-stationary for the period considered.
} 
Figure 1: Short Term Nominal Interest Rates

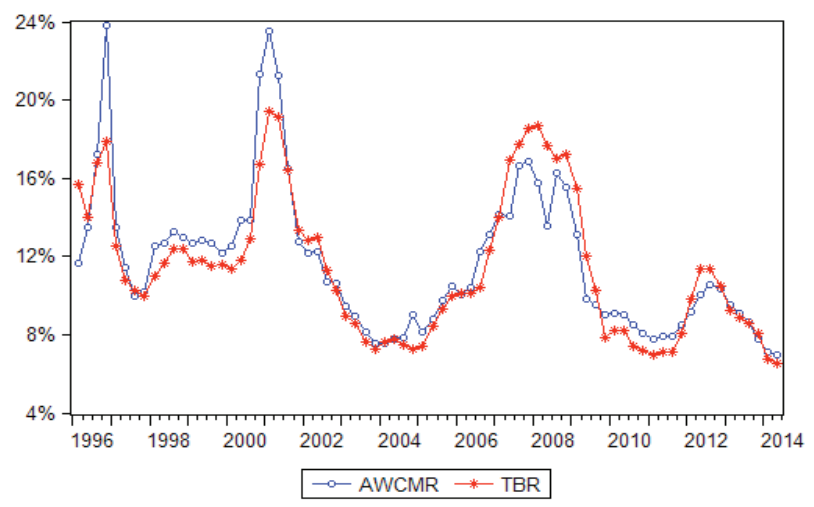

Source: CBSL

The output gap ${ }^{29}$ is an important variable in the modern macroeconomic models. Determination of the output gap is, however, challenging since the potential output is not directly observable. Among others, Giorno et al. (1995), De Brouwer et al. (1998), Orphanides and Van Norden (2002) and Gerlach and Yiu (2004) suggest alternative methods of determining output gap, explaining some of the pitfalls and complexities of the different techniques. Out of these methods, approximating the potential output by the HodrickPrescott filtered trend ${ }^{30}$ (HP trend), is widely used, as it is easy to compute and communicate. Thus, the present study employs the same, as an approximation to the potential output. ${ }^{31}$

Exchange rate can be introduced to the monetary policy rule in different ways. ${ }^{32}$ Ball (1999), for instance proposes two possibilities: either to include through an index made out of a weighted average of inflation and exchange to use as the policy instrument replacing the nominal rate, or to use the exchange rate in the righthand side of the equation. Following Patra and Kapur (2012), this study uses annualised quarter-on-quarter variation in the quarterly average exchange rate in the policy rule.

\footnotetext{
${ }^{29}$ The output gap is the percentage deviation of output $(y)$ from its potential value $(y *)$, thus defined as: $\left[\left(y-y^{*}\right) / y *\right]$.

${ }^{30}$ The HP filter separates a time series into growth and cyclical components, thus, the decomposed series does not contain any seasonality. HP filter minimise the variance of the cyclical component, subject to a penalty for variations in the second difference of the growth term. Potential output estimation using the HP filter depends on the choice of the smoothing parameter, $\lambda$, and Hodrick and Prescott (1997), advocate $\lambda=1600$ with quarterly data which is pretty standard now.

${ }^{31}$ For other de-trending techniques, see for instance: Lucas (1972), Beveridge and Nelson (1981), Blanchard and Quah (1988), Baxter and King (1999), and Kuttner (1994).

${ }^{32}$ Note that the exchange rate is expressed as the number of domestic currency (Sri Lankan Rupees) per one US Dollar (i.e. SLR/USD).
} 
Among the different inflation indices including the Wholesale Price Index (WPI), Colombo Consumers Price Index (CCPI) and GDP deflator, the present study uses CCPI as it is the commonly used measure. Sri Lanka has not yet implemented an inflation targeting monetary policy framework, formally. The CBSL, however, signaled its ambition to maintain inflation at the midpoint of the single digit range, in the medium term. Accordingly, this study uses 4 to 6 percent as the inflation target for Sri Lanka. ${ }^{33}$ Accordingly, the year on year change in CCPI is employed in determining the inflation and then, the deviation of inflation from its implied target value is computed as per the rule specification. Figure 2 given below depicts dynamics of the variable used in the estimation of Taylor Rule, over the sample period.

Figure 2: Time Plot of Variables Used for the Taylor Rule Estimation

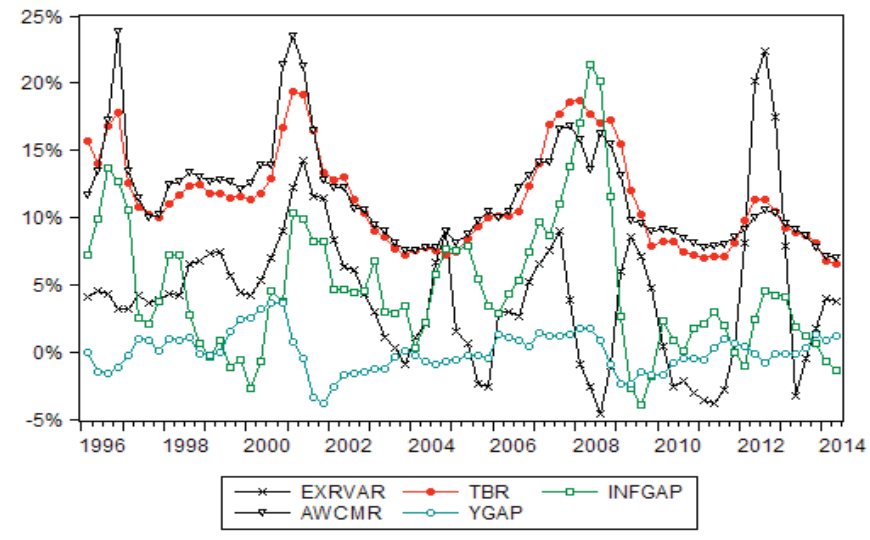

Source: CBSL, Department of Census and Statistics (DCS) and author's calculations

Exchange rate variation (EXRVAR) appears to be having a moderate association with short run nominal interest rates until 2004, but it disappears thereafter. ${ }^{34}$ Fully floating exchange rate management implemented by the CBSL in 2001, may explain this behaviour to some extent. Inflation gap (INFGAP) reflects a moderately strong association with short run nominal interest rates probably with a lag. Single digit lower inflation recorder since mid2009 is notable and it is partly attributable to the CBSL's intense focus on curtailing inflation.

\footnotetext{
${ }^{33}$ This approach is followed in other similar studies for countries where a formal inflation target is unavailable. (See for instance, Patra and Kapur (2012)). Accordingly, for simplicity, the mid value of the range which is 5 per cent is used as the point target of inflation in this study. Alternatively, relaxing this simple assumption, one can use inflation averages over certain periods as implicit inflation targets.

${ }^{34}$ Correlation coefficient of EXRVAR with AWCMR is only 0.31 for the full period considered.
} 
GDP gap measure (YGAP) displays a moderate counter cyclical relationship, with a lag of apparently 2-3 quarters, as the YGAP curve approximately resembles the mirror image of the short-term interest curves. This suggests the forward-looking policy reaction of the CBSL, in stabilising the output gap.

The average inflation gap for the full sample period is 4.7 and this is highly influenced by the low inflation observed after 2008. The two alternative measures of the short-term interest rate, weighted average call money rate and T-bill rate recorded a mean value of 11.6 percent and 11.7 percent respectively. The average depreciation of the exchange rate, as reflected from EXRVAR is computed to be 4.3 percent and the variability of the series seems to be slightly lower in the period prior to fully floating. The mean value of the output gap is zero, as expected, since it is calculated with respect to the long-term trend approximated by the HP trend.

The two alternative policy instruments for the McCallum Rule specifications, growth rates of reserve money and narrow money (i.e. monetary base M1), are plotted in Figure 3. As expected, it reveals that the two series are highly associated with each other, as evident from the moderately strong correlation coefficient of 0.66 , between them.

\section{Figure 3: Growth Rates of Reserve Money and Narrow Money (Monetary Aggregate M1)}

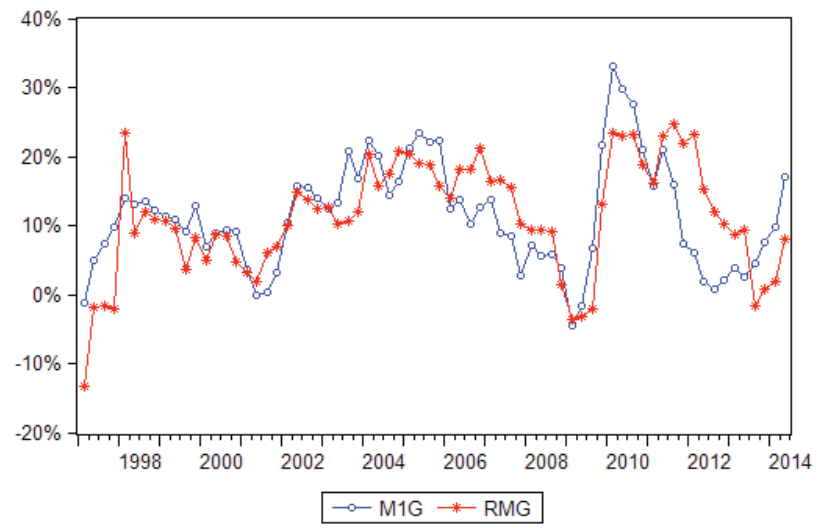

Source: CBSL and author's calculations

Figure 4 reveals dynamics of all four variables used in the McCallum rule estimation. It is evident that the nominal GDP growth rate (NGDPG) weakly follows the growth rate of the monetary bases, with a lag, accordingly, this behaviour seems to support the McCallum rule in Sri Lankan data. 


\section{Figure 4: Timeseries Plot of Variables Used for the McCallum Rule Estimation}

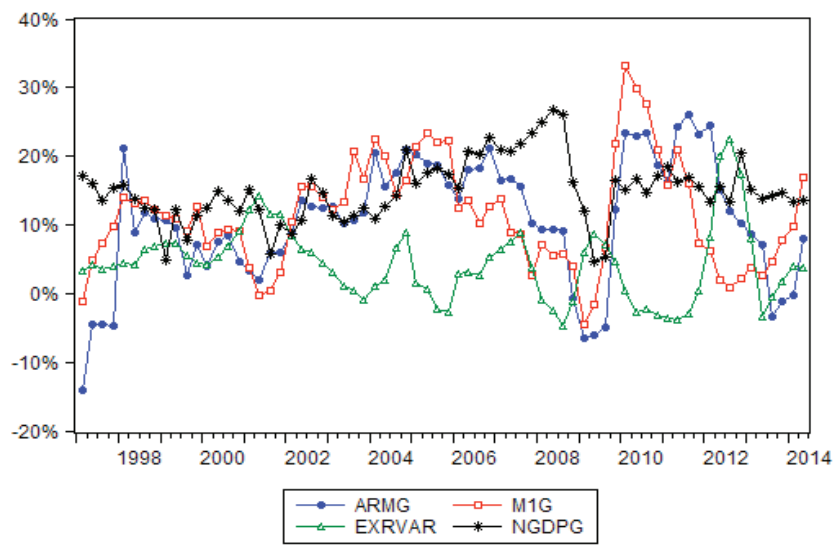

Source: CBSL, DCS

Exchange rate variation, on the other hand, weakly resembles the mirror image of the monetary aggregate dynamics curves, particularly the Narrow Money Growth (M1G) curve. This again makes sense as lower growth in the monetary base implies tightening the monetary policy stance which leads to appreciation pressure (or slowing down depreciation) in the exchange rate. None of the two figures seems to suggest any data issues such as discontinuities, outliers or changing variability.

If some variables to be included in the equations are stationary while others are not, taking first-difference or de-trending is useful to prevent possible spurious correlation problems. When the data series is not sufficiently long enough, however, the unit roots tests such as Augmented Dickey-Fuller or Phillips-Perron tests are not strong enough to distinguish between a series having a unit roots issue and a series with slow mean-reverting ${ }^{35}$ property. Accordingly, these tests could be biased towards non-rejecting the null hypothesis of unit root for data series with short sample periods. The present study contains data series with 72 data points which is sufficiently long enough to check possible non-stationarities. Visually, none of the data plots seem to suggest any non-stationarities. It is, however, formally tested with the Augmented Dickey-Fully test and the results are given in the Table 2.

\footnotetext{
${ }^{35} \mathrm{~A}$ mean-reverting time series is normally stationary since the finite variance assures that a drift in data will revert before long, without moving far away from its mean.
} 
Table 2: Stationarity of Variables (Unit root test)

\begin{tabular}{|c|c|c|}
\hline \multirow[t]{2}{*}{ Variable } & \multicolumn{2}{|c|}{ "ADF Test (Reported values) } \\
\hline & t-Statistic & Probability* \\
\hline$A W C M R\left(i_{t}\right)$ & -2.947295 & 0.0450 \\
\hline $\operatorname{TBR}\left(i_{t}\right)$ & -2.770401 & 0.0676 \\
\hline $\operatorname{INFGAP}\left(\pi_{t}-\pi *\right)$ & -3.988917 & 0.0025 \\
\hline$Y G A P\left(y_{t}-\tilde{y}_{t}\right)$ & -3.821691 & 0.0042 \\
\hline $\operatorname{EXRVAR}\left(\Delta e_{t}\right)$ & -5.718961 & 0.0000 \\
\hline $\operatorname{NDGPG}\left(\Delta x_{t}\right)$ & -3.366251 & 0.0156 \\
\hline$A R M G\left(\Delta m_{t}\right)$ & -3.171793 & 0.0261 \\
\hline$M 1 G\left(\Delta m_{t}\right)$ & -3.389851 & 0.0147 \\
\hline
\end{tabular}

As evident from Table 2, all the necessary variables, except the Treasury bill rate, are stationary at 5 percent level of significance. The Treasury bill rate is also stationary at 10 percent level of significance and therefore data are free from any non-stationarity issues. This stationarity of the data is attributable to the fact that all of them, except nominal interest rates, are either in the gap-form ${ }^{36}$ or in the first-difference form, implying that they are de-trended and thus stationary. Interestingly, all the variables which need to be used in estimating the policy rules mentioned above are stationary and do not show any data issues such as outliers, breakages and increasing/decreasing volatility.

\subsection{Results and discussion}

The different monetary policy reaction functions discussed above are estimated with Sri Lankan data. Following Clarida et al. (1998b), the policy rules and parameters are estimated with the ordinary least squares (OLS) method for contemporaneous and backward-looking policy rules while generalised method of moments (GMM) is utilized in the forward-looking specifications.

\subsubsection{Taylor rule estimation}

For the Taylor rule, two alternative policy instruments AWCMR and TBR are used for each of the three functional forms. The results are summarised in Appendix A. ${ }^{37}$

\footnotetext{
36 i.e. Expressed either as a difference of the corresponding target value or long-term trend value.

${ }^{37}$ Results are presented in three individual tables for the contemporaneous, backward-looking and forward-looking cases.
} 


\section{Contemporaneous specification}

The results of the contemporaneous Taylor rule specifications are summarised in Appendix A.1. The baseline scenario, where contemporaneous values of inflation, output gap and the first lag of the short-term interest rate ${ }^{38}$ respond to the policy rules AWCMR and TBR, are shown in columns 2 and 4 of the table, respectively. The same rule, however, augmented with nominal exchange rate is also tested and the corresponding results are shown in columns 3 and 5 of the same table.

Interestingly, the results show that almost all of the coefficients in the four specifications of the contemporaneous case are highly significant. The inflation and output coefficients have the correct positive sign with both policy variables, AWCMR and TBR. The magnitude of the inflation coefficient is moderate and less than unity in all four cases. The highest value of the long-run inflation coefficient reported with TBR as the policy instrument is only 0.68 . The fact that the contemporaneous specification disregards intrinsic lag in the monetary policy transmission mechanism, ${ }^{39}$ could be partly attributable to this moderate value.

The coefficient of the output gap, in comparison, is larger and the corresponding long-run coefficients are greater than unity. The output-gap coefficient, which is larger than the inflation coefficient, suggests that the CBSL conducts monetary policy giving greater prominence to output stabilisation than inflation. Alternatively, it could be due to the lower sensitivity of output to the nominal interest rate which stipulates an aggressive response of the monetary policy in stabilising output, as argued in Hayo and Hofmann (2006)..$^{40}$ It could also imply possible inaccuracies in computing the latent variable, the output gap, as highlighted in Taylor (1999b). This requires careful attention since academic literature, including McCallum (2001), argues that it is undesirable to respond to the output gap strongly.

The CBSL smooths out the interest rate strongly, as suggested by the reported high and significant value for the interest rate persistence parameter in all four specifications and this is in line with the previous findings of the studies conducted in Sri Lanka such as Perera and Jayawickrema (2013). This suggests that CBSL conducts monetary policy, making interest rate changes smoothly in small short steps in the desired direction, rather

\footnotetext{
${ }^{38}$ This is to account for the interest rate smoothing behaviour of the central bank.

${ }^{39}$ There are a few Sri Lankan studies such as Amarasekara (2005), Perera and Wickramanayake (2013) and Ghazanchyan (2014) that suggest the existence of a lag in monetary policy transmission mechanism.

${ }^{40}$ In a paper that compares the European Central Bank's (ECB) conduct of monetary policy with that of the Bundesbank, Hayo and Hofmann (2006) show that the relatively stronger reaction of the ECB to deviations of output from trend may be attributed to a lower interest rate sensitivity of output in the Euro area compared to Germany, rather than to differences in the policy preferences of the ECB and the Bundesbank. A similar behaviour is reported in the recent papers, Patra and Kapur (2012) and Perera and Jayawickrema (2013) as well.
} 
than making immediate abrupt changes. This is a precautionary measure followed by many monetary authorities to mitigate possible risks in changing the policy stance under uncertain macroeconomic environments.

These findings also show that the CBSL does respond to the exchange rate, though not very strongly, as reflected by the long-run exchange rate coefficient of 0.3 , which is statistically significant. As Sri Lanka is a small open economy exposed to foreign shocks, it is sensible to expect that the CBSL responds to the exchange rate in conducting monetary policy. All specifications are associated with fairly high R-squared statistics, ${ }^{41}$ implying that observed data fits with the regression line satisfactorily and this is particularly visible where the policy instrument is the Treasury bill rate (TBR).

\section{Backward-looking specification}

Appendix A.2 summarises the estimation results for the backward-looking specification of the Taylor rule. Resembling Table A.1, the results for the baseline scenario, with AWCMR and TBR as the policy instruments, is shown in columns 2 and 4 of the table, while the results for the rule augmented with exchange rate are depicted in columns 2 and 4 respectively.

In contrast to the contemporaneous case, the inflation coefficient is statistically insignificant with AWCMR and smaller in magnitude in all specifications. The output gap coefficient is still greater than one and very significant. Exchange rate responsiveness has declined marginally and the figures are statistically insignificant as opposed to the contemporaneous case. Interest rate smoothing is strong and significant and the strength of smoothing is similar to in the previous case. The regression is not very different to that of the contemporaneous case as suggested by the adjusted R-squared statistic. The overall implications of the backward-looking specification do not seem to be very rational, as it implies that the CBSL neither responds to inflation nor to exchange rate in some specifications, as reflected by the small and significant coefficients.

\section{Forward-looking specification}

Appendix A.3 summarises the results for the forward-looking specifications. The two alternative short-term interest rates AWCMR and TBR are used as the policy instruments,

\footnotetext{
${ }^{41} \mathrm{R}$-squared statistics should, however, be used with caution due to two potential problems: firstly, the R-squared increases every time a predictor is added to a model and secondly over fitting the model may produce misleading $\mathrm{R}$ squared statistics.
} 
which is similar to the previous case, however, with one quarter ahead values of inflation, output gap and exchange rate change, as opposed to the previous two cases. The coefficients on inflation, output gap and exchange rate have the right positive sign and the values are statistically significant in all forward-looking specifications. Interestingly, the long-run inflation coefficient is larger than unity when the policy instrument is TBR. ${ }^{42}$ Similarly, to the contemporaneous and backward-looking specifications, the output coefficient is large and strongly significant. Further, the exchange rate coefficient has the right sign; however, it is only significant when AWCMR is the instrument. Analogous to the contemporaneous and backward-looking cases, interest rate smoothing is high and significant in all the forward-looking specifications.

\subsubsection{McCallum rule estimation}

This study uses both the backward-looking and forward-looking versions of the McCallum rule, augmented with responses to exchange rate dynamics. ${ }^{43}$ There is an important difference between the estimation of the McCallum rule and the Taylor rule, with regards to the output growth term: the McCallum rule defines the output growth term as the trend growth minus the actual growth. This is in contrast to the Taylor rule which defines the term as actual growth minus trend growth. Thus, a positive coefficient is expected for the output growth term in the McCallum rule, which can be sensibly interpreted as when the gap increases (i.e. actual output growth is lower than the trend growth), the rule advocates for an expansion in base money, and vice-versa.

In line with related literature, including McCallum (2000) and Patra and Kapur (2012), the target value of the nominal GDP growth for Sri Lanka is taken as 10.3 percent. This is the summation of the target value of inflation (i.e. 5 percent for Sri Lanka, as in the Taylor rule estimation) and the average real GDP growth rate for the country in the last 12 years, which is 5.3 percent. ${ }^{44}$

\section{Backward-looking specification}

Appendix A.4 summarises the results for the backward-looking specification of the McCallum rule. Positive and statistically significant coefficient values are obtained for the output growth when the policy instrument is M1G. These coefficients are estimated to be 0.25 and 0.24 respectively for the specifications with and without the exchange rate. McCallum

\footnotetext{
${ }^{42}$ Satisfying this condition is required in achieving determinacy in a closed economy policy rule which does not respond to output gap, as per Taylor (1999a). In the present case, however, the conditions are different.

${ }^{43}$ The original McCallum rule is of backward-looking form and I estimate an alternative forward-looking specification, following Patra and Kapur (2012).

${ }^{44}$ Computed for the period 2000 to 2012
} 
suggests a range of values from 0.25 to 0.5 for this coefficient for mature economies and proposes slightly lower values for developing economies. Thus, the results obtained are consistent with McCallum's specification. When the policy instrument is the adjusted reserve money growth rate (ARMG), however, the corresponding coefficients are smaller (0.12 and 0.10 respectively) and are statistically insignificant. The coefficient on the exchange rate is correctly signed but small and insignificant, implying that the CBSL does not respond to exchange rate changes strongly in conducting the monetary policy. Moreover, all four specifications indicate strong policy smoothing which is more evident with the growth rate of monetary aggregate M1 with a coefficient of 0.82 . Results suggest that where the policy instrument is M1G, the backward-looking McCallum rule explains monetary policy reaction behaviour in Sri Lanka better compared to that of ARMG, as evident from the higher $\mathrm{R}$ squared value together with the lower standard error of regression.

\section{Forward-looking specification}

The results for the forward-looking form of the McCallum rule ${ }^{45}$ are summarised in Appendix A.3. The sign of the coefficient on the output growth is correct, but the value is insignificant when the policy instrument is ARMG. Similarly, the coefficient of the exchange rate is statistically not different from zero when the policy instrument is ARMG. When M1G is used as the instrument, however, both these coefficients are marginally significant at 10 percent level of significance, with fairly large magnitudes of 0.39 and 0.41 for the output growth coefficient and -0.34 for the exchange rate coefficient.

Similar to the backward-looking case, policy smoothing is strong and significant in all four specifications. Large standard errors of the regression in the McCallum rule models compared to the Taylor rule specifications suggest that the fitted values deviate considerably from their actual, which is not a desirable feature.

\section{Actual and fitted policy response}

Selecting the best model among the alternatives is an important part of any statistical analysis. This is relevant here since I am interested in identifying the rule which explains the monetary policy behaviour in Sri Lanka most reasonably. Many authors, including Bozdogan (1987), Hurvich and Tsai (1989) Raftery (1995) and Kadane and Lazar (2004), have examined the question of model selection and suggest several tools for selecting

\footnotetext{
${ }^{45}$ Estimation in the forward-looking specification employs GMM methodology, using the first lag of the following variables as instruments: ARMG, M1G, NGDPG and EXRVAR.
} 
the best model. Among these criteria, residual sum of squares (RSS), standard error of regression (SE), Akaike information criterion (AIC), Schwartz information criterion (SC) and Hannan-Quinn information criteria (HQ) are widely used in academic literature. A ranking of the models based on the RSS and SE is reported in Table 3 below. ${ }^{46}$ The RSS reports the squared value of the difference between actual and fitted, while SE reports the square root of RSS after dividing it by the effective degrees of freedom. Hence a model associated with a lower RSS and SE is preferred over a model with larger RSS and SE. In addition, a F-test is performed to check whether there is a significant difference between the model that includes exchange rate and the corresponding model that excludes exchange rate (EXRVAR), in each of the scenarios. For this purpose, the model without EXRVAR is treated as the unrestricted model while the one without EXRVAR is treated as the restricted model and performed the F-test as outlined in Wooldridge (2009). Accordingly, the F-statistic, $F=\frac{\left(S S R_{r}-S S R_{u r}\right) / q}{S S R_{u r} /(n-k-1)}$, where $\mathrm{SSR}_{\mathrm{r}}, \mathrm{SSR}_{\mathrm{ur}}, \mathrm{q}, \mathrm{n}$ and $\mathrm{k}$ represent Residual Sum of Squares of the restricted model, Residual Sum of Squares of the unrestricted model, the number of restrictions imposed, the total number of observations and the total number of independent variables in the model, respectively.

Table 3 leads to several important insights. Firstly, it suggests that the backward-looking and contemporaneous specifications outperform the forward-looking specifications, hence it does not support the idea that the CBSL was following a forward-looking monetary policy rule during the period under consideration. Secondly, the results imply that the growth rate of narrow money (M1G) is better than adjusted reserve money growth (ARMG) in characterizing the McCallum rule. Thirdly, it is found that the Treasury bill rate (TBR) is always better than the average weighted call money rate (AWCMR) in characterising the Taylor rule in all three specifications: contemporaneous, backward-looking and forward-looking. This suggests that the CBSL takes the movements of the Treasury bill rate into account more seriously than the movements in the call money rate in conducting the monetary policy. Fourth, in almost all Taylor rules, the specification with the exchange rate variation outperforms the corresponding rule without the exchange rate variation. This implies that the exchange rate variation has some explanatory power in describing the policy reaction. This equally says that the CBSL does respond to exchange rate variations in conducting monetary policy. Finally, the results depict that the contemporaneous Taylor rule where TBR responds to inflation, output gap and exchange rate variation explains the monetary policy reaction most appropriately among the alternative rules.

\footnotetext{
${ }^{46}$ These two criteria are used due to their simple and transparent nature. It is also noted that AIC, SC and HQ also give similar rankings as RSS and SE with respect to these models
} 
Table 3: Model selection

\begin{tabular}{|c|c|c|c|c|c|c|c|}
\hline \multicolumn{4}{|c|}{ Rule } & \multirow{2}{*}{$\begin{array}{l}\text { RSS } \\
243.152\end{array}$} & \multirow{2}{*}{$\begin{array}{l}\text { SE } \\
1.891\end{array}$} & \multirow{2}{*}{$\begin{array}{l}\text { F-test } \\
\text { calcu. } \\
4.26^{* *}\end{array}$} & \multirow{2}{*}{$\begin{array}{l}\text { Rank } \\
7\end{array}$} \\
\hline \multirow[t]{12}{*}{ Taylor } & Contemporaneous & AWCMR & With EXRVAR & & & & \\
\hline & & & Without EXRVAR & 258.626 & 1.936 & & 9 \\
\hline & & TBR & With EXRVAR & 89.992 & 1.150 & $6.83^{* *}$ & 1 \\
\hline & & & Without EXRVAR & 99.161 & 1.199 & & 4 \\
\hline & Backward & AWCMR & With EXRVAR & 252.060 & 1.925 & 2.30 & 8 \\
\hline & & & Without EXRVAR & 260.730 & 1.944 & & 10 \\
\hline & & TBR & With EXRVAR & 96.178 & 1.189 & 1.44 & 2 \\
\hline & & & Without EXRVAR & 98.238 & 1.193 & & 3 \\
\hline & Forward & AWCMR & With EXRVAR & 260.677 & 1.972 & $3.14^{*}$ & 11 \\
\hline & & & Without EXRVAR & 272.881 & 2.003 & & 12 \\
\hline & & TBR & With EXRVAR & 115.722 & 1.314 & $5.53 * *$ & 5 \\
\hline & & & Without EXRVAR & 125.366 & 1.358 & & 6 \\
\hline \multirow[t]{8}{*}{ McCallum } & Backward & ARMG & With EXRVAR & 1829.532 & 5.305 & 0.54 & 6 \\
\hline & & & Without EXRVAR & 1844.396 & 5.286 & & 5 \\
\hline & & M1G & With EXRVAR & 1211.460 & 4.317 & 0.03 & 2 \\
\hline & & & Without EXRVAR & 1212.004 & 4.285 & & 1 \\
\hline & Forward & ARMG & With EXRVAR & 1914.005 & 5.469 & 0.60 & 8 \\
\hline & & & Without EXRVAR & 1931.266 & 5.451 & & 7 \\
\hline & & M1G & With EXRVAR & 1235.887 & 4.394 & $16.39 * *$ & 3 \\
\hline & & & Without EXRVAR & 1538.126 & 4.865 & & 4 \\
\hline
\end{tabular}

RSS: residual sum of squares, SE: standard error of regression.

F-test shows the calculated values of the test statistics; ${ }^{* * *} \mathrm{p}<0.01,{ }^{* *} \mathrm{p}<0.05,{ }^{*} \mathrm{p}<0.1$.

The fitted values of the best three rules together with the corresponding actual policy instruments are given in Figures 5 and 6, for both the Taylor and McCallum rules.

Figure 5 shows that the alternative rules match the actual short-term interest rate dynamics fairly well. Discrepancies among the three alternative rules are also not large. The fitted values slightly lag behind the actuals in the beginning of the period, however, the magnitude is small. In the first two peaks, which occurred in 1996 and 2001, the actual figures are slightly sharper than the fitted values. In line with the argument made in McCallum (2000), this could imply that the CBSL responds more aggressively than suggested by the rule. The reversal effects, where actuals are lower than the level advocated by the rules, are observed in the peaks in 2008 and 2012. 
Figure 5: Actual TBR and the fitted values of the same with the best three Taylor rules

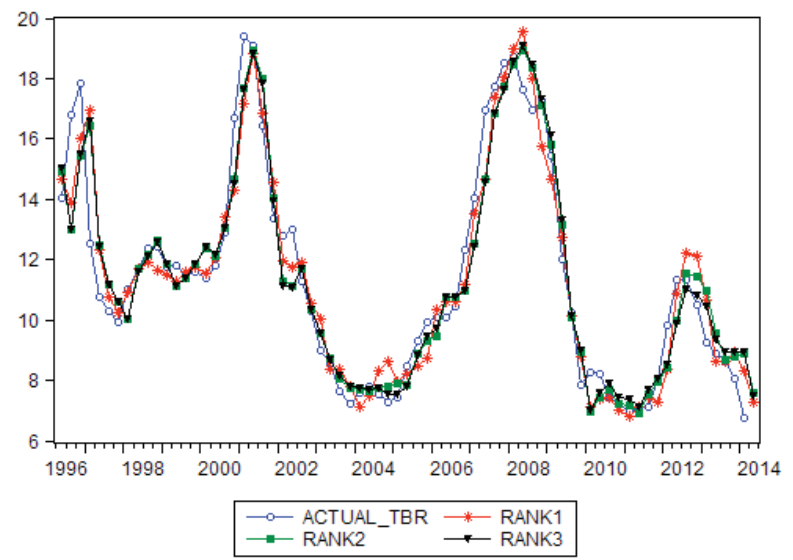

Source: CBSL and author's computations

Figure 6: Actual monetary base growth rate (M1G) and the fitted values of the same with the best three McCallum rules

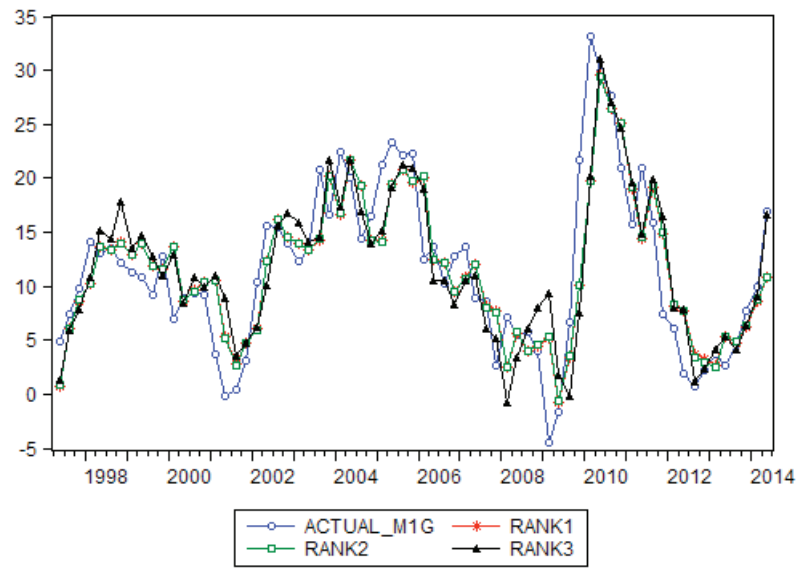

Source: CBSL and author's computations

As reflected by Figure 6 and Table 3, the residual gaps between actuals and fitted values are larger in the McCallum rule, suggesting that it is less suited for explaining the monetary policy reaction in Sri Lanka than the Taylor rule. The question of whether a policy rule proposed is 
associated with a unique determinate solution is an important consideration in deciding on the most suitable alternative policy rule among several alternatives (Bernanke and Woodford, 1997; Clarida et al., 1998a; Bullard and Mitra, 2002; Bullard and Mitra, 2007). For a simple interest rate feedback rule of the form $i_{t}=\bar{l}_{t}+\emptyset_{\pi} \pi_{t}$, Woodford (2003) shows that the rational-expectations equilibrium paths of inflation and nominal interest rate are determinate when the inflation coefficient $\emptyset_{\pi}>1$ and are indeterminate, if instead $0 \leq \emptyset_{\pi}<1$. He further shows that when interest rate smoothing presents, equilibrium is determinate if and only if $\emptyset_{\pi} /(1-\rho)>1$ where $\varrho$ is the smoothing parameter. Accordingly, he interprets this condition as the case where an eventual increase in the nominal interest rate as a result of the sustained increase in the inflation rate is more than one-for-one. In an open economy version of the policy rule that is similar to the one I consider in the study, the determinacy condition is more complex and depends on the other parameters of the economy as argued in Gali (2009) and Araujo (2014), for instance.

\subsection{Endogeneity and Attenuation bias concerns}

Estimation of monetary policy rules using the ordinary least squares (OLS) method could sometimes lead to potentially inconsistent estimates of policy parameters due to the issue of endogeneity. Monetary authorities respond to variables such as inflation, output gap and exchange rate that are endogenous to monetary policy shocks. Endogeneity arises as a result of a correlation between explanatory variables and the error term, thus creating a bias. Although Instrumental Variables (IV) are usually employed to address this issue, ${ }^{47}$ the validity of such potential variables depends on various unobserved factors of the economic environment. Thus, among others, Carvalho et al (2018) argue in favor of OLS estimation of monetary policy rules. They maintain that the endogeneity bias is small since monetary policy shocks explain only a small fraction of the variance of regressors typically included in monetary policy rules. Further, using simulations, they show that, for realistic sample sizes, the OLS estimator of monetary policy parameters outperforms IV estimators. Accordingly, this study limits the analysis to OLS estimation of monetary policy rules only.

The expected variables in forward-looking specifications of the rules are approximated by the leads of the corresponding observed variables. This could possibly lead to attenuation bias, arising from possible measurement errors, ${ }^{48}$ either in dependent or explanatory variables. Attenuation bias influences an estimator toward zero and accordingly the magnitude of an estimator with attenuation bias is smaller in magnitude than the absolute value of the

\footnotetext{
${ }^{47}$ See for instance, Clarida, Gali and Gertler (2000)

${ }^{48}$ Measurement error refers to a situation where the true empirical value of a variable cannot be observed or measured with a precise degree of accuracy. Accordingly, the error is the difference between the actual value of that variable and what can be observed or measured
} 
parameter. ${ }^{49}$ However, in the present study, the number of observations used to compute data points for certain variables such as for AWCMR, etc. are substantially high. Further, the true empirical value of some variables such as the Treasury bill rate is observable and measurable. Accordingly, the likelihood of attenuation bias seems to be negligible in the present study and adjusting for attenuation bias cannot be found in the literature on monetary policy rules.

\section{Conclusion}

This paper empirically assesses the appropriateness of the Taylor rule and the McCallum rule in characterising the monetary policy conduct behaviour in Sri Lanka. It regards the two approaches as alternatives, rather than as competing rivals. Over the last two decades, the Taylor rule has gained more recognition and become the most widely used policy rule in the central banks of the world, owing to its ability to describe modern monetary policy more sensibly than alternative rules. Testing both of these policy rules is, however, important in the Sri Lankan context since the CBSL still uses broad money as an indicative intermediate variable in the conduct of monetary policy, although interest rate (AWCMR) is the main monetary policy instrument.

The empirical results suggest that the backward-looking and contemporaneous specifications outperform the forward-looking specifications and therefore the findings do not support the idea that the CBSL followed a forward-looking monetary policy rule during the period under consideration. Results also suggest that the movements of the Treasury bill rate explain the conduct of the monetary policy better than the call money rate (AWCMR). Moreover, it implies that the CBSL does respond to exchange rate variations in conducting monetary policy. It is also found that the CBSL is strongly smoothing out policy action, as it implements policy action in small steps in the desired direction without making abrupt changes to alleviate possible risks that could hamper the economy otherwise. A considerably larger output gap coefficient, in comparison to the inflation coefficient is notable. This, however, could be due to lower sensitivity of output to interest rate or alternatively due to the inaccuracies in determining the unobservable output gap. Therefore, further investigation is needed to find out such possibilities in explaining this difference. The results suggest that the contemporaneous Taylor rule, where TBR responds to inflation, output gap and exchange rate variation, explains the monetary policy reaction most appropriately among the alternative rules.

Some studies find that monetary policy reaction does not take exchange rate changes into account, as opposed to the findings of the present study. Taylor and Williams (2010), for instance, find that the interest rate rules which react to exchange rate underperforms those that do not. Moreover, Taylor (2001) argues that the inclusion of exchange rate in

${ }^{49}$ For details see Wooldridge, J.M., (2003), Introductory Econometrics, 2nd ed., Thomson. 
the policy rule could lead to a deterioration of output performance. Thus, the response of the CBSL to exchange rate variations in conducting monetary policy might not be optimal. In-depth investigations are, however, needed to establish this stance in the Sri Lankan context.

When monetary policy is conducted without a rule, policymakers have a bias towards inflationary monetary policy; however, if they are bound to follow a rule, inflation would be lower (McCallum, 1990; Stark and Croushore, 1998 and Taylor and Williams, 2010). An important conjecture highlighted by McCallum (1999a) and Woodford (2001a) is, however, that the policy rules would not need to be followed literally or slavishly by the monetary authorities; instead, such rules can be used for indicative purposes, probably as a starting point for policy discussions and recommendations. 


\section{References}

Aleem, A. and Lahiani, A. (2011). Monetary policy rules for a developing country: Evidence from Pakistan, Journal of Asian Economics, 22(6):483-494.

Amarasekara, C. (2005). Interest rate pass-through in Sri Lanka, Staff Studies, Central Bank of Sri Lanka 35(1/2):1-32.

Araujo, E. (2014). Determinacy and learnability of equilibrium in a small open economy with sticky wages and prices. Technical report, No. 376, Central Bank of Brazil.

Ball, L. M. (1999). Policy rules for open economies, Monetary Policy Rules, pages 127-156. University of Chicago Press.

Barro, R. J. and Gordon, D. B. (1983). Rules, discretion and reputation in a model of monetary policy, Journal of Monetary Economics, 12(1):101-121.

Baxter, M. and King, R. G. (1999). Measuring business cycles: approximate band-pass filters for economic time series, Review of Economics and Statistics, 81(4):575-593.

Bernanke B. S. and Mishkin F. S. (1997). Inflation Targeting: A New Framework for Monetary Policy? The Journal of Economic Perspectives, Vol. 11, No. 2 (Spring, 1997), pp. 97-116, URL: http://www.jstor.org/stable/2138238

Bernanke, B. S. and Woodford, M. (1997). Inflation forecasts and monetary policy, Technical Report, National Bureau of Economic Research.

Beveridge, S. and Nelson, C. R. (1981). A new approach to decomposition of economic time series into permanent and transitory components with particular attention to measurement of the business cycle, Journal of Monetary Economics, 7(2):151-174.

Blanchard, O. J. and Quah, D. (1988). The dynamic effects of aggregate demand and supply disturbances. Technical Report, National Burean of Economic Research.

Boamah, M. I. (2012). Taylor rule and monetary policy in Ghana, International Journal of Economics and Finance, 4(7): p15.

Bozdogan, H. (1987). Model selection and Akaike's information criterion (AIC): The general theory and its analytical extensions, Psychometrika, 52(3):345-370.

Bullard, J. and Mitra, K. (2002). Learning about monetary policy rules, Journal of Monetary Economics, 49(6):1105-1129.

Bullard, J. and Mitra, K. (2007). Determinacy, learnability, and monetary policy inertia. Journal of Money, Credit and Banking, 39(5):1177-1212. 
Carvalho C., Nechio F. and Tristao T. (2018), Taylor Rule Estimation by OLS, Federal Reserve Bank of San Francisco, Working Paper Series, pp 01-38.

CBSL Annual Reports, 2017 and 2018, Central Bank of Sri Lanka

Chung, H., Laforte, J.P., Reifschneider, D., and Williams, J. C. (2010). Have we underestimated the probability of hitting the zero-lower bound? In conference, Revisiting Monetary Policy in a Low Inflation Environment, Federal Reserve Bank of Boston, October, volume 13.

Clarida, R., Gali, J., and Gertler, M. (1998a). Monetary policy rules and macroeconomic stability: evidence and some theory, Technical Report, National Bureau of Economic Research.

Clarida, R., Gali, J., and Gertler, M. (1998b). Monetary policy rules in practice: some international evidence, European Economic Review, 42(6):1033-1067.

Clarida, R. H. and Gertler, M. (1997). How the Bundesbank conducts monetary policy, Reducing Inflation: Motivation and Strategy, 363-412, University of Chicago Press.

De Brouwer, G. et al. (1998). Estimating output gaps, DSpace on 2011- 01-05T08.

Edge, R. M., Laubach, T., and Williams, J. C. (2010). Welfare-maximising monetary policy under parameter uncertainty, Journal of Applied Econometrics, 25(1):129-143.

Eggertsson, G. B. and Woodford, M. (2003), The zero bound on interest rates and optimal monetary policy, Brookings Papers on Economic Activity.

Esanov, A., Merkl, C., and de Souza, L. V. (2005). Monetary policy rules for Russia. Journal of Comparative Economics, 33(3):484-499.

Fair, R. C. and Howrey, E. P. (1996). Evaluating alternative monetary policy rules, Journal of Monetary Economics, 38(2):173-193.

Fuhrer, J. C. and Madigan, B. F. (1997). Monetary policy when interest rates are bounded at zero, Review of Economics and Statistics, 79(4):573-585.

Gali, J. (2009). Monetary policy, inflation, and the business cycle: An introduction to the new Keynesian Framework, Princeton University Press.

Gerlach, S. and Smets, F. (1999). Output gaps and monetary policy in the emu area, European Economic Review, 43(4):801-812.

Gerlach, S. and Yiu, M. S. (2004). Estimating output gaps in Asia: A cross-country study, Journal of the Japanese and International Economies, 18(1):115-136.

Ghazanchyan, M. M. (2014). Unraveling the Monetary Policy Transmission Mechanism in Sri Lanka. International Monetary Fund Number 14-190. 
Giorno, C., Richardson, P., Roseveare, D., and Van den Noord, P. (1995). Estimating potential output, output gaps and structural budget balances Working Papers, Economics Department, OECD.

Hayo, B. and Hofmann, B. (2006). Comparing monetary policy reaction functions: ECB versus Bundesbank, Empirical Economics, 31(3):645-662.

Hodrick, R. J. and Prescott, E. C. (1997). Postwar us business cycles: an empirical investigation. Journal of Money, credit, and Banking, pages 1-16.

Hurvich, C. M. and Tsai, C.-L. (1989). Regression and time series model selection in small samples. Biometrika, 76(2):297-307.

Kadane, J. B. and Lazar, N. A. (2004). Methods and criteria for model selection, Journal of the American Statistical Association, 99(465):279-290.

Khakimov, O. A., Erdogan, L., and Uslu, N. C. (2010). Assessing monetary policy rule in Turkey, International Journal of Economic Perspectives, 4(1):319.

Kozmenko, S. and Savchenko, T. (2013). Development of an explicit rule of monetary policy for the economy of Ukraine, Investment Management and Financial Innovations, (1):8-19.

Kuttner, K. N. (1994). Estimating potential output as a latent variable, Journal of Business \& Economic Statistics, 12(3):361-368.

Kydland, F. E. and Prescott, E. C. (1977). Rules rather than discretion: The inconsistency of optimal plans. The Journal of Political Economy, 473-491.

Levin, A. (1996). A comparison of alternative monetary policy rules in the Federal Reserve board's multi-country model. BIS Conference Papers, volume 2, pages 340-366.

Llosa, L.G. and Tuesta, V. (2008). Determinacy and learnability of monetary policy rules in small open economies, Journal of Money, Credit and Banking, 40(5):1033-1063.

Lucas, R. E. (1972). Expectations and the neutrality of money, Journal of Economic Theory, $4(2): 103-124$.

McCallum, B. T. (1988). Robustness properties of a rule for monetary policy. CarnegieRochester conference series on public policy, volume 29, pages 173-203. NorthHolland.

McCallum, B. T. (1990). Could a monetary base rule have prevented the great depression? Journal of Monetary Economics, 26(1):3-26.

McCallum, B. T. (1999a). Issues in the design of monetary policy rules, Handbook of Macroeconomics, 1:1483-1530. 
McCallum, B. T. (1999b). Recent developments in monetary policy analysis: the roles of theory and evidence, Journal of Economic Methodology, 6(2):171-198.

McCallum, B. T. (2000). Alternative monetary policy rules: a comparison with historical settings for the United States, the United Kingdom, and Japan. Technical Report, National Bureau of Economic Research.

McCallum, B. T. (2001). Should monetary policy respond strongly to output gaps? Technical Report, National Bureau of Economic Research.

Nelson, E. (2001). UK monetary policy 1972-97: a guide using Taylor rules, CEPR Discussion Paper No. 2931

Orphanides, A. (2001). Monetary policy rules based on real-time data, American Economic Review, pages 964-985.

Orphanides, A. and Van Norden, S. (2002). The unreliability of output-gap estimates in real time, Review of Economics and Statistics, 84(4):569-583.

Orphanides, A., Wieland, V., et al. (1998). Price stability and monetary policy effectiveness when nominal interest rates are bounded at zero, Division of Research \& Statistics and Monetary Affairs, Federal Reserve Board.

Patra, M. D. and Kapur, M. (2012). Alternative monetary policy rules for India, IMF Working Paper.

Perera, A. and Wickramanayake, J. (2013). Monetary transmission in the emerging country context: the case of Sri Lanka, Conference Proceedings, $5^{\text {th }}$ International Research Conference Central Bank of Sri Lanka.

Perera, R. and Jayawickrema, V. (2013). Monetary policy rules in practice: Evidence for Sri Lanka. Conference Proceedings, 6th International Conference, Central Bank of Sri Lanka.

Raftery, A. E. (1995). Bayesian model selection in social research. Sociological Methodology, 25:111-164.

Rotemberg, J. and Woodford, M. (1997). An optimization based econometric framework for the evaluation of monetary policy. In NBER Macroeconomics Annual 1997, Volume 12, pages 297-361. MIT Press.

Rudebusch, G. D. (2001). Is the fed too timid? monetary policy in an uncertain world, Review of Economics and Statistics, 83(2):203-217.

Stark, T. and Croushore, D. (1998). Evaluating McCallum's rule when monetary policy matters, Journal of Macroeconomics, 20(3):451-485. 
Svensson, L. E. (2000). Open-economy inflation targeting, Journal of International Economics, 50(1):155-183.

Taylor, J. B. (1993a). Discretion versus policy rules in practice, Carnegie-Rochester Conference Series on Public Policy, volume 39, pages 195-214. Elsevier.

Taylor, J. B. (1993b). Macroeconomic policy in a world economy: from econometric design to practical operation, WW Norton New York ISBN 0-393-96316-0.

Taylor, J. B. (1999a). A historical analysis of monetary policy rules, Monetary Policy Rules, pages 319-348. University of Chicago Press.

Taylor, J. B. (1999b). The robustness and efficiency of monetary policy rules as guidelines for interest rate setting by the European Central Bank, Journal of Monetary Economics, 43(3):655-679.

Taylor, J. B. (2001). The role of the exchange rate in monetary-policy rules, American Economic Review, pages 263-267.

Taylor, J. B. and Williams, J. C. (2010). Simple and robust rules for monetary policy, Technical Report, National Bureau of Economic Research.

Wimanda, R. E., Turner, P. M., and Hall, M. J. (2012). Monetary policy rules for Indonesia: which type is the most efficient? Journal of Economic Studies, 39(4):469-484.

Woodford, M. (2001a). Imperfect common knowledge and the effects of monetary policy, Technical Report, National Bureau of Economic Research.

Woodford, M. (2001b). The Taylor rule and optimal monetary policy, American Economic Review, pages 232-237.

Woodford, M. (2003). Comment on: Multiple-solution indeterminacies in monetary policy analysis, Journal of Monetary Economics, 50(5):1177-1188.

Woodford, M. and Walsh, C. E. (2005). Interest and prices: Foundations of a theory of monetary policy, Macroeconomic Dynamics, 9, 2005, 462-468. 


\section{Appendices}

\section{A1 Case 1: The contemporaneous Taylor rule}

$$
i_{t}=\emptyset_{0}+\emptyset_{\pi}\left(\pi_{t}-\pi^{*}\right)+\emptyset_{y} \operatorname{ygap}_{t}+\emptyset_{e} \Delta e_{t}+\emptyset_{i} i_{t-1}+\varepsilon_{t}
$$

Table A1: Summary statistics for the contemporaneous Taylor rule

\begin{tabular}{|c|c|c|c|c|}
\hline \multirow{3}{*}{ Description } & \multicolumn{4}{|c|}{ Policy instrument } \\
\hline & \multicolumn{2}{|c|}{ Call Money (AWCMR) } & \multicolumn{2}{|c|}{ T-bill (TBR) } \\
\hline & $\begin{array}{c}\text { Including } \\
\text { exchange rate }\end{array}$ & $\begin{array}{c}\text { Excluding } \\
\text { exchange rate }\end{array}$ & $\begin{array}{c}\text { Including } \\
\text { exchange rate }\end{array}$ & $\begin{array}{c}\text { Excluding } \\
\text { exchange rate }\end{array}$ \\
\hline \multicolumn{5}{|l|}{ Parameters estimates } \\
\hline Constant $\quad\left(\emptyset_{0}\right)$ & $\begin{array}{c}2.52 \\
(3.26)^{* * *}\end{array}$ & $\begin{array}{c}2.30 \\
(2.93)^{* * *}\end{array}$ & $\begin{array}{c}1.38 \\
(2.74)^{* * *}\end{array}$ & $\begin{array}{c}1.15 \\
(2.22)^{* *}\end{array}$ \\
\hline INFGAP $\quad\left(\emptyset_{\pi}\right)$ & $\begin{array}{c}0.16 \\
(3.07)^{* * *}\end{array}$ & $\begin{array}{c}0.13 \\
(2.54)^{* *}\end{array}$ & $\begin{array}{c}0.13 \\
(3.72)^{* * *}\end{array}$ & $\begin{array}{c}0.10 \\
(2.91)^{* * *}\end{array}$ \\
\hline YGAP $\quad\left(\varnothing_{y}\right)$ & $\begin{array}{c}0.49 \\
(3.19)^{* * *}\end{array}$ & $\begin{array}{c}0.45 \\
(2.89)^{* * *}\end{array}$ & $\begin{array}{c}0.50 \\
(4.80)^{* * *}\end{array}$ & $\begin{array}{c}0.43 \\
(4.51)^{* * *}\end{array}$ \\
\hline EXRVAR $\quad\left(\emptyset_{e}\right)$ & $\begin{array}{c}0.10 \\
(2.08)^{* *}\end{array}$ & - & $\begin{array}{c}0.07 \\
(2.63)^{* *}\end{array}$ & - \\
\hline $\operatorname{AWCMR}(-1)\left(\emptyset_{i}\right)$ & $\begin{array}{c}0.68 \\
(8.71)^{* * *}\end{array}$ & $\begin{array}{c}-0.74 \\
(10.23)^{* * *}\end{array}$ & - & $\begin{array}{l}- \\
-\end{array}$ \\
\hline $\operatorname{TBR}(-1) \quad\left(\emptyset_{i}\right)$ & - & - & $\begin{array}{c}0.79 \\
(14.55)^{* * *}\end{array}$ & $\begin{array}{c}0.85 \\
(16.63)^{* * *}\end{array}$ \\
\hline Estimation method & OLS & OLS & OLS & OLS \\
\hline Observations & 73 & 73 & 73 & 73 \\
\hline Adjusted R-squared & 0.74 & 0.73 & 0.90 & 0.89 \\
\hline SE of regression & 1.89 & 1.94 & 1.15 & 1.20 \\
\hline F-statistics & 53.67 & 66.89 & 159.07 & 193.19 \\
\hline Prob. (F-statistics) & 0.00 & 0.00 & 0.00 & 0.00 \\
\hline Long-run coefficient & & & & \\
\hline Inflation & 0.51 & 0.52 & 0.63 & 0.68 \\
\hline Output & 1.52 & 1.76 & 2.10 & 2.81 \\
\hline Exchange rate & 0.30 & - & 0.35 & - \\
\hline
\end{tabular}

Notes: t-statistics are in the parenthesis, ${ }^{* *} p<0.01,{ }^{* *} p<0.05,{ }^{*} p<0.1$.

The long-run coefficients are computed as per Woodford (2001b), for instance, the long run coefficient of inflation = inflation coefficient/ (1-interest rate smoothing coefficient), and so on. 


\section{A2 Case 2: The backward-looking Taylor rule}

$$
i_{t}=\emptyset_{0}+\emptyset_{\pi}\left(\pi_{t-1}-\pi^{*}\right)+\emptyset_{y} y_{g a p_{t-1}}+\emptyset_{e} \Delta e_{t-1}+\emptyset_{i} i_{t-1}+\varepsilon_{t}
$$

Table A2: Summary statistics for the backward-looking Taylor rule

\begin{tabular}{|c|c|c|c|c|c|}
\hline \multirow{3}{*}{\multicolumn{2}{|c|}{ Description }} & \multicolumn{4}{|c|}{ Policy instrument } \\
\hline & & \multicolumn{2}{|c|}{ Call Money (AWCMR) } & \multicolumn{2}{|c|}{ T-bill (TBR) } \\
\hline & & $\begin{array}{c}\text { Including } \\
\text { exchange rate }\end{array}$ & $\begin{array}{c}\text { Excluding } \\
\text { exchange rate }\end{array}$ & $\begin{array}{c}\text { Including } \\
\text { exchange rate }\end{array}$ & $\begin{array}{c}\text { Excluding } \\
\text { exchange rate }\end{array}$ \\
\hline \multicolumn{6}{|c|}{ Parameters estimates } \\
\hline Constant & $\left(\emptyset_{0}\right)$ & $\begin{array}{c}2.87 \\
(3.50)^{* * *}\end{array}$ & $\begin{array}{c}2.62 \\
(3.23)^{* * *}\end{array}$ & $\begin{array}{c}1.56 \\
(2.86)^{* * *}\end{array}$ & $\begin{array}{c}1.39 \\
(2.63)^{* *}\end{array}$ \\
\hline INFGAP(-1) & $\left(\emptyset_{\pi}\right)$ & $\begin{array}{c}0.10 \\
(1.75)^{*}\end{array}$ & $\begin{array}{l}0.07 \\
(1.3)\end{array}$ & $\begin{array}{c}0.07 \\
(1.86)^{*}\end{array}$ & $\begin{array}{c}0.06 \\
(1.49)\end{array}$ \\
\hline YGAP(-1) & $\left(\varnothing_{y}\right)$ & $\begin{array}{c}0.65 \\
(3.97)^{\text {*** }}\end{array}$ & $\begin{array}{c}0.59 \\
(3.68)^{* * *}\end{array}$ & $\begin{array}{c}0.56 \\
(5.64)^{* * *}\end{array}$ & $\begin{array}{c}0.53 \\
(5.49)^{* * *}\end{array}$ \\
\hline EXRVAR(-1) & $\left(\emptyset_{e}\right)$ & $\begin{array}{c}0.07 \\
(1.53)\end{array}$ & - & $\begin{array}{c}0.04 \\
(1.21)\end{array}$ & - \\
\hline AWCMR(-1) & $\left(\emptyset_{i}\right)$ & $\begin{array}{c}0.68 \\
(7.99)^{* * *}\end{array}$ & $\begin{array}{c}-0.74 \\
(9.70)^{* * *}\end{array}$ & - & - \\
\hline $\operatorname{TBR}(-1)$ & $\left(\emptyset_{i}\right)$ & - & - & $\begin{array}{c}0.81 \\
(13.17)^{* * *}\end{array}$ & $\begin{array}{c}0.85 \\
(15.86)^{* * *}\end{array}$ \\
\hline Estimation me & od & OLS & OLS & OLS & OLS \\
\hline Observations & & 73 & 73 & 73 & 73 \\
\hline Adjusted R-sq & red & 0.73 & 0.73 & 0.89 & 0.89 \\
\hline SE of regressic & & 1.93 & 1.94 & 1.19 & 1.19 \\
\hline F-statistics & & 51.17 & 66.17 & 147.75 & 195.22 \\
\hline Prob. (F-statis & & 0.00 & 0.00 & 0.00 & 0.00 \\
\hline Long-run coef & cient & & & & \\
\hline Inflation & & 0.32 & 0.27 & 0.39 & 0.36 \\
\hline Output & & 2.04 & 2.27 & 0.92 & 3.45 \\
\hline Exchange $r$ & & 0.23 & - & 0.19 & - \\
\hline
\end{tabular}

Notes: t-statistics are in the parenthesis, ${ }^{* * *} p<0.01,{ }^{* *} p<0.05,{ }^{*} p<0.1$.

The long-run coefficients are computed as per Woodford (2001b), for instance, the long run coefficient of inflation = inflation coefficient/ (1-interest rate smoothing coefficient), and so on. 


\section{A3 Case 3: The forward-looking Taylor rule}

$$
i_{t}=\emptyset_{0}+\emptyset_{\pi}\left(E_{t}\left[\pi_{t+1}\right]-\pi^{*}\right)+\emptyset_{y} E_{t}\left[\operatorname{ygap}_{t+1}\right]+\emptyset_{e} E_{t} \Delta e_{t+1}+\emptyset_{i} i_{t-1}+\varepsilon_{t}
$$

Table A3: Summary statistics for the forward-looking Taylor rule

\begin{tabular}{|c|c|c|c|c|c|}
\hline \multirow{3}{*}{\multicolumn{2}{|c|}{ Description }} & \multicolumn{4}{|c|}{ Policy instrument } \\
\hline & & \multicolumn{2}{|c|}{ Call Money (AWCMR) } & \multicolumn{2}{|c|}{ T-bill (TBR) } \\
\hline & & $\begin{array}{l}\text { Including } \\
\text { exchange rate }\end{array}$ & $\begin{array}{l}\text { Excluding } \\
\text { exchange rate }\end{array}$ & $\begin{array}{c}\text { Including } \\
\text { exchange rate }\end{array}$ & $\begin{array}{l}\text { Excluding } \\
\text { exchange rate }\end{array}$ \\
\hline \multicolumn{6}{|c|}{ Parameters estimates } \\
\hline Constant & $\left(\emptyset_{0}\right)$ & $\begin{array}{c}1.67 \\
(2.06)^{* *}\end{array}$ & $\begin{array}{c}2.92 \\
(2.86)^{* * *}\end{array}$ & $\begin{array}{c}1.18 \\
(1.90)^{*}\end{array}$ & $\begin{array}{c}1.15 \\
(1.82)^{*}\end{array}$ \\
\hline $\operatorname{INFGAP}(+1)$ & $\left(\emptyset_{\pi}\right)$ & $\begin{array}{c}0.26 \\
(2.99)^{* * *}\end{array}$ & $\begin{array}{c}0.19 \\
(3.71)^{* * *}\end{array}$ & $\begin{array}{c}0.22 \\
(3.26)^{* * *}\end{array}$ & $\begin{array}{c}0.20 \\
(5.30)^{* * *}\end{array}$ \\
\hline YGAP(+1) & $\left(\emptyset_{y}\right)$ & $\begin{array}{c}0.62 \\
(3.18)^{* * *}\end{array}$ & $\begin{array}{c}0.49 \\
(1.75)^{*}\end{array}$ & $\begin{array}{c}0.54 \\
(3.54)^{* * *}\end{array}$ & $\begin{array}{c}0.55 \\
(3.65)^{* * *}\end{array}$ \\
\hline $\operatorname{EXRVAR}(+1)$ & $\left(\emptyset_{e}\right)$ & $\begin{array}{c}0.12 \\
(1.86)^{*}\end{array}$ & - & $\begin{array}{c}0.03 \\
(0.37)\end{array}$ & - \\
\hline AWCMR(-1) & $\left(\emptyset_{i}\right)$ & $\begin{array}{c}0.71 \\
(7.82)^{* * *}\end{array}$ & $\begin{array}{c}0.69 \\
(7.08) * * *\end{array}$ & $\begin{array}{l}- \\
-\end{array}$ & - \\
\hline $\operatorname{TBR}(-1)$ & $\left(\emptyset_{i}\right)$ & - & - & $\begin{array}{c}0.78 \\
(8.51)^{* * *}\end{array}$ & $\begin{array}{c}0.81 \\
(12.99)^{* * *}\end{array}$ \\
\hline \multicolumn{2}{|c|}{ Estimation method } & GMM & GMM & GMM & GMM \\
\hline \multicolumn{2}{|l|}{ Observations } & 72 & 72 & 72 & 72 \\
\hline \multicolumn{2}{|c|}{ Adjusted R-squared } & 0.72 & 0.72 & 0.86 & 0.86 \\
\hline \multicolumn{2}{|c|}{ SE of regression } & 1.97 & 2.00 & 1.31 & 1.36 \\
\hline \multicolumn{2}{|l|}{ J-statistics } & 0.40 & 2.36 & 0.47 & 0.53 \\
\hline \multicolumn{2}{|c|}{ Prob. (J-statistics) } & 0.52 & 0.31 & 0.49 & 0.76 \\
\hline \multicolumn{6}{|c|}{ Long-run coefficient } \\
\hline Inflation & & 0.89 & 0.61 & 1.00 & 1.02 \\
\hline Output & & 2.11 & 1.58 & 2.50 & 2.84 \\
\hline Exchange $\mathrm{r}$ & & 0.40 & - & 0.15 & - \\
\hline
\end{tabular}

Notes: t-statistics are in the parenthesis, ${ }^{* * *} p<0.01$, ** $p<0.05$, * $p<0.1$.

Instruments for the GMM estimate: INFGAP(-1), YGAP(-1), AWCMR(-1), TBR(-1) AN EXRVAR(-1).. J-test reports p-value for test for over-identifying restrictions for GMM estimates.

The long-run coefficients are computed as per Woodford (2001b), for instance, the long run coefficient of inflation = inflation coefficient/(1-interest rate smoothing coefficient), and so on. 
A4 Case 4: The backward-looking McCallum rule

$$
\Delta m_{t}=c_{1}+c_{2}\left(\Delta x^{*}-x_{t-1}\right)+c_{3} \Delta e_{t-1}+c_{4} \Delta m_{t-1}+\varepsilon_{t}
$$

Table A4: Summary statistics for the backward-looking McCallum rule

\begin{tabular}{|c|c|c|c|c|}
\hline \multirow{3}{*}{ Description } & \multicolumn{4}{|c|}{ Policy instrument } \\
\hline & \multicolumn{2}{|c|}{ Reserve Money (ARMG) } & \multicolumn{2}{|c|}{ M1growth (M1G) } \\
\hline & $\begin{array}{c}\text { Including } \\
\text { exchange rate }\end{array}$ & $\begin{array}{c}\text { Excluding } \\
\text { exchange rate }\end{array}$ & $\begin{array}{c}\text { Including } \\
\text { exchange rate }\end{array}$ & $\begin{array}{c}\text { Excluding } \\
\text { exchange rate }\end{array}$ \\
\hline Parameters estimates & & & & \\
\hline Constant & $\begin{array}{c}4.02 \\
(2.97)^{* * *}\end{array}$ & $\begin{array}{c}3.43 \\
(3.17)^{* * *}\end{array}$ & $\begin{array}{c}3.59 \\
(2.39)^{* *}\end{array}$ & $\begin{array}{c}3.39 \\
(3.32)^{* * *}\end{array}$ \\
\hline$($ TGT-NGDPG $(-1))\left(\mathrm{c}_{2}\right)$ & $\begin{array}{c}0.12 \\
(0.41)\end{array}$ & $\begin{array}{c}0.10 \\
(0.49)\end{array}$ & $\begin{array}{c}0.25 \\
(2.11)^{* *}\end{array}$ & $\begin{array}{c}0.24 \\
(2.15)^{* *}\end{array}$ \\
\hline EXRVAR(-1) & $\begin{array}{l}-0.09 \\
(-0.73)\end{array}$ & $\begin{array}{l}- \\
-\end{array}$ & $\begin{array}{l}-0.21 \\
(-0.18)\end{array}$ & - \\
\hline EXRVAR(-1) & $\begin{array}{c}0.75 \\
(9.73)^{* * *}\end{array}$ & $\begin{array}{c}0.75 \\
(9.94)^{* * *}\end{array}$ & - & - \\
\hline $\operatorname{AWCMR}(-1)$ & - & - & $\begin{array}{c}0.82 \\
(10.46)^{* * *}\end{array}$ & $\begin{array}{c}0.82 \\
(12.33)^{* * *}\end{array}$ \\
\hline Estimation method & OLS & OLS & OLS & OLS \\
\hline Observations & 69 & 69 & 69 & 69 \\
\hline Adjusted R-squared & 0.60 & 0.60 & 0.68 & 0.69 \\
\hline SE of regression & 5.31 & 5.29 & 4.32 & 4.28 \\
\hline F-statistics & 35.28 & 53.03 & 50.31 & 76.57 \\
\hline Prob. (F-statistics) & 0.00 & 0.00 & 0.00 & 0.00 \\
\hline
\end{tabular}

Notes: t-statistics are in the parenthesis, ${ }^{* * *} p<0.01,{ }^{*} p p<0.05,{ }^{*} p<0.1$. 


\section{A5 Case 5: The forward-looking McCallum rule}

$$
\Delta m_{t}=c_{1}+c_{2}\left(\Delta x^{*}-E_{t} x_{t+1}\right)+c_{3} \Delta E_{t} e_{t+1}+c_{4} \Delta m_{t-1}+\varepsilon_{t}
$$

Table A5: Summary statistics for the forward-looking McCallum rule

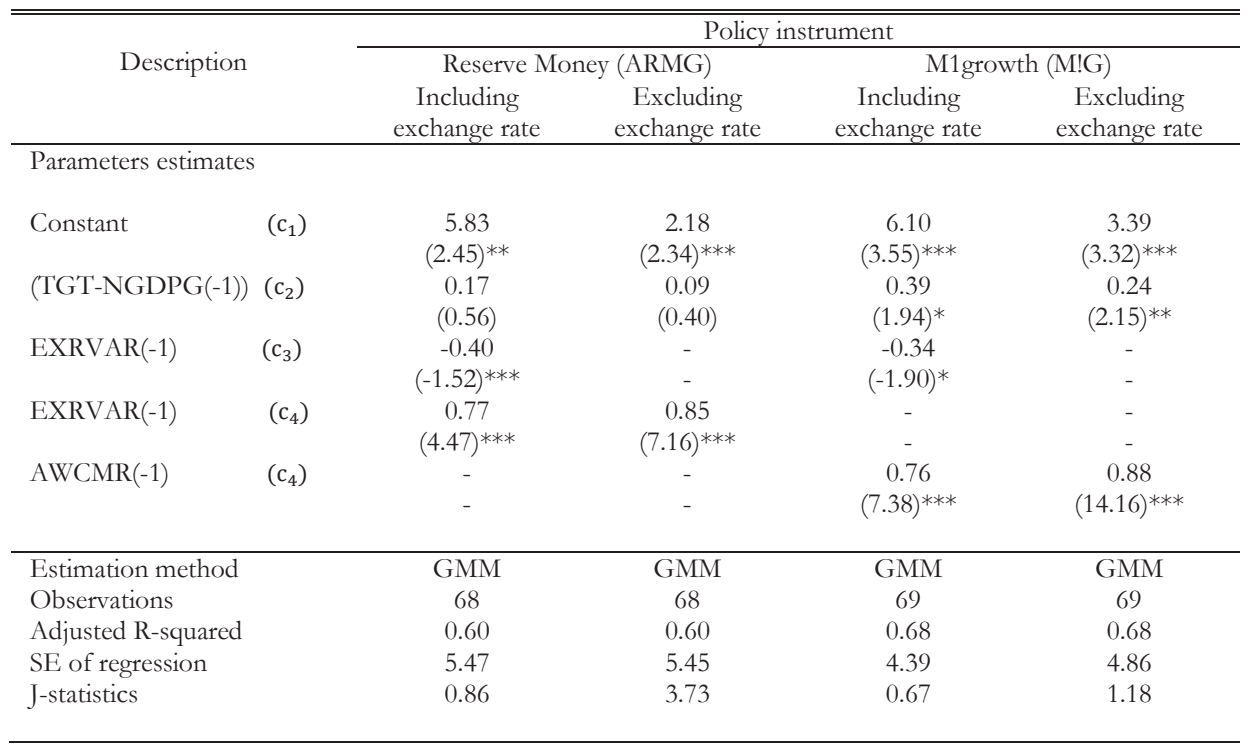

Notes: t-statistics are in the parenthesis, ${ }^{* *} p<0.01,{ }^{* *} p<0.05,{ }^{*} p<0.1$. 